\title{
فعالية برنامج قائم على أنشطة اللعب الموجه في تطوير اللغة الرياضياتية لاى طفل الحضانة
}

\author{
إعداد \\ د/سحر فتحي عبد المحسن'
}

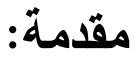

إن حرص الدولة على وجود برنامج لإعداد معلمة الحضانة يمثل اتجاهاً عالمياً باعتباره استثمارًا للموارد البشرية في المستقبل والذي يبدأ منذ ميلاد الطفل عن طريق الرعاية والتعليم عالي الجودة، فالخبرات المبكرة للطفل تساعده على بناء قاعدة معرفية قوية تدعم فهمه وتؤثر على تكوين شخصيته مدى الحباة.

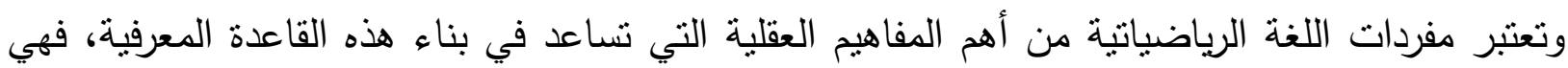

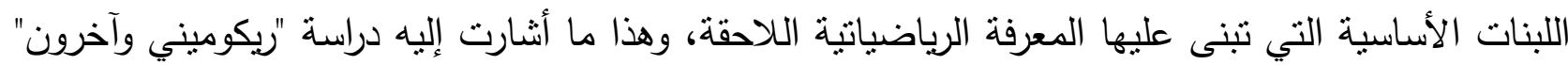
Riccomini, P. J., et al الكفاءة الرياضياتية بشكل خاص، حيث أكدت نتائج البحوث والدراسات السابقة تَقَم أطفال الحضانة عند التحاقهم

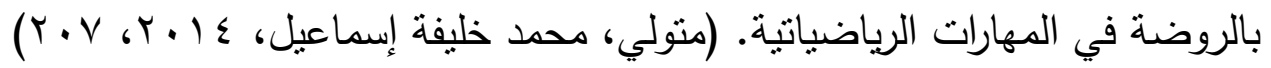

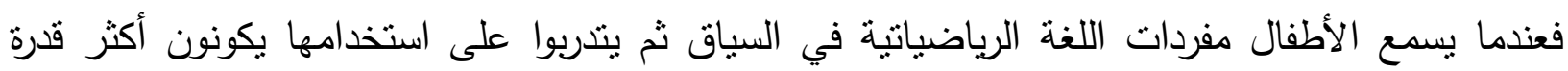

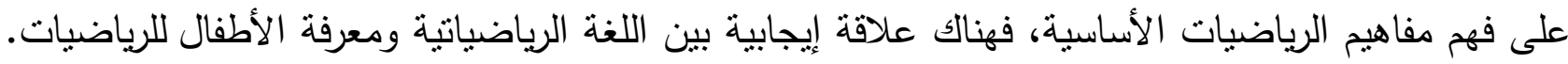

(Frye, D., et al, 2013, 42)

وقد أكدت العديد من الدراسات مثل دراسة "جينسبيرج وآخرون" Ginsburg, H. P., et al, (^...

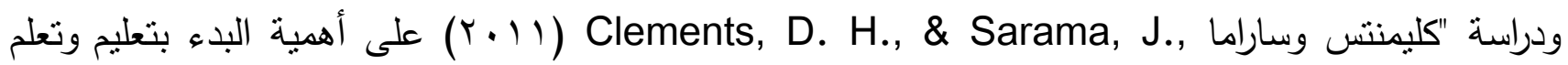
الرياضيات في مرحلة الطفولة المبكرة حيث بطور الأطفال الصغار (من سن ب إلى ه سنوات) رياضيات يومية التهاء شاملة فيتعلمون الرياضيات بشكل أعمق وأكثر مما يُتوقع.

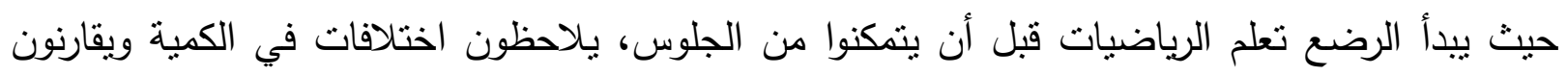

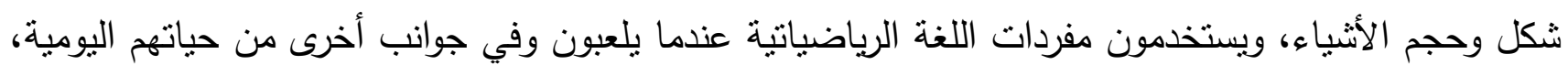

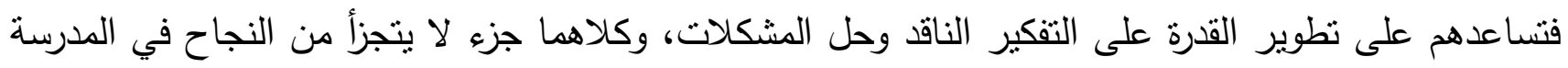

وفي الحياة. (Harris, B., Petersen, D., 2019, 1)

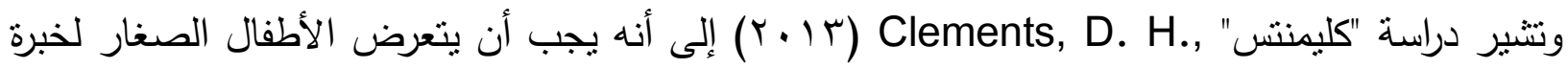
الرياضيات من خلال مناهج قائمة على الممارسات التعليمية الفعالة.

مدرس بقسم العلوم التريوية - كلية التربية للطفولة المبكرة/جامعة الفيوم 
فالدور الهام لمقدمي الرعاية يتمثل في جعل الرياضيات التي تحدث في الحياة اليومية ملموسة ومرئية

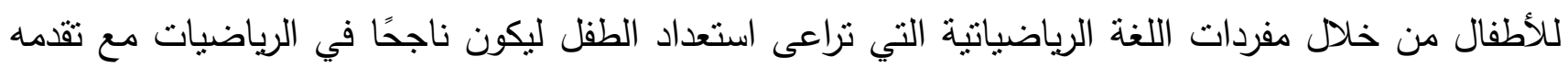

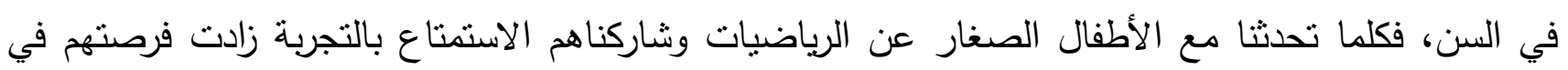

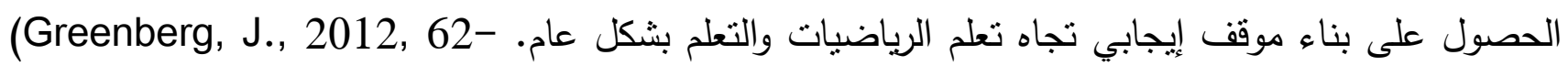

(Harris, B., Petersen, D., لذا ينبغي أن يتفاعل الأطفال مع البالغين لتعلم مفردات اللغة الرياضياتية

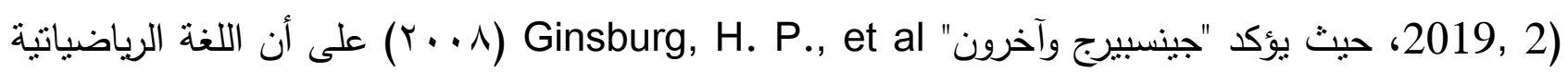

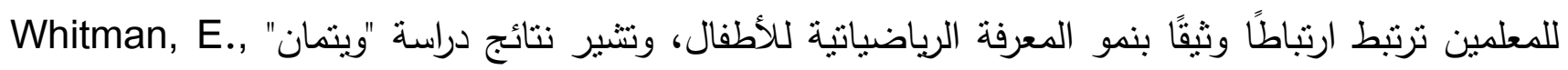
(10 ( 10) إلى أن استخدام اللغة الرياضياتية من قبل معلمي الطفولة المبكرة تتبئ بتطور المفاهيم الرياضياتية للطفل. (Ginsburg, H. P., et al, 2008, 5)

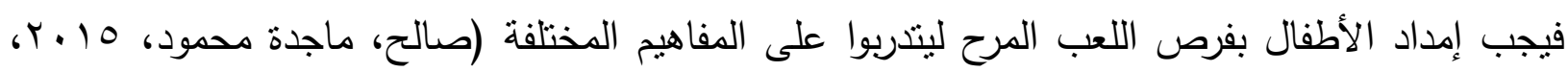

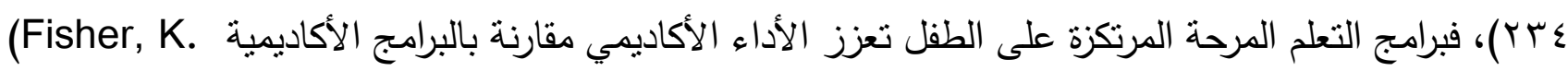

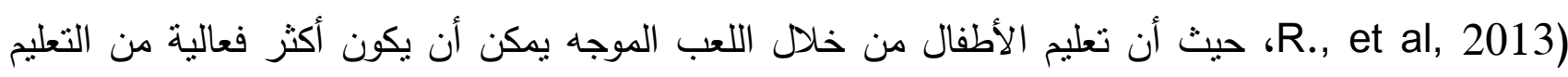

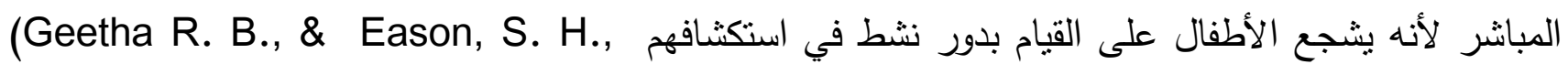
(2015,29، لذا رأت الباحثة الإستفادة من إعداد وتطبيق برنامج قائم على أنشطة اللعب الموجه لنطوير اللغة لإنة الرياضياتية لاى طفل الحضانة. مشكلة البحث: البهي

بدأ إحساس الباحثة بالمشكلة من خلال منابعة التنريب الميداني في الحضانات المختلفة التي تحمل فلسفات

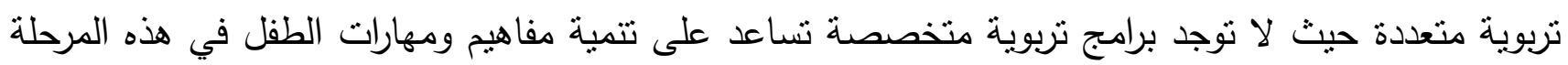

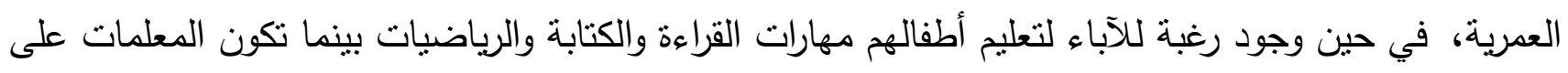

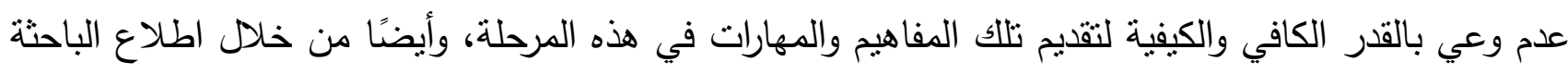

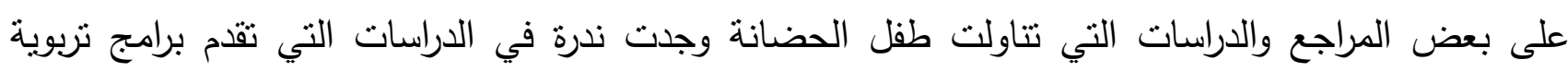

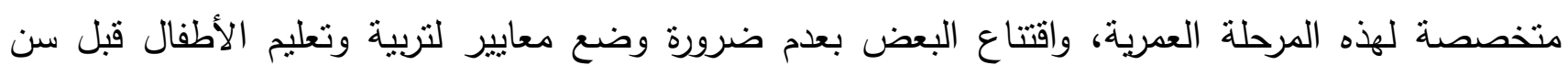

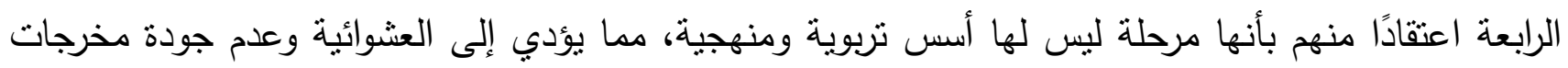
التعلم في تلك المرحلة المهمة من حياة الأطفال.

(Clements, D. H., \& وجميع الأطفال في سنواتهم الأولى بحتاجون إلى معرفة قوية بالرياضيات ( Sarama, J., 2011, 968)

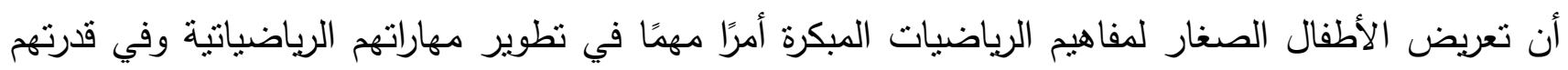
على استخدام الرياضيات لاحقًا في الحياة ونظوير تفكيرهم ومهارات حل المشكلة لديهم مما يساهم في النجاح 
Clements, D. H., \& Sarama, J. "داخل المدرسة وخارجها، بينما أكدت دراسة "كليمنتس وساراما

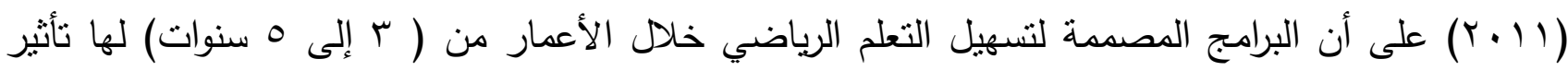
إيجابي قوي على حياة هؤلاء الأطفال لسنوات عديدة بعد ذللك.

ولقد أظهرت الأبحاث أن اللغة هي عنصاء الاطفر محوري لنجاح الرياضيات، فيمكن أن تنتبأ معرفة المتعلم

بمفردات اللغة الرياضياتية بمستوى الأداء الرياضي لديه. (Riccomini, P. J., et al, 2015, 236) وهناك العديد من التحديات التي تواجه الأطفال في تعلمهم للغة الرياضياتية دنها التواصل الرياضي فهو

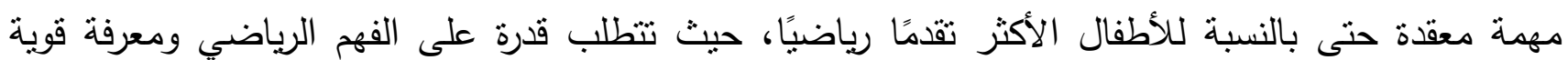
بالمفردات الرياضياتية. (Riccomini, P. J., et al, 2015, 237)

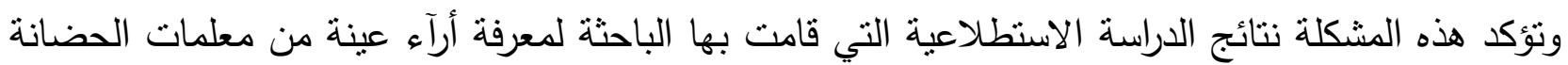

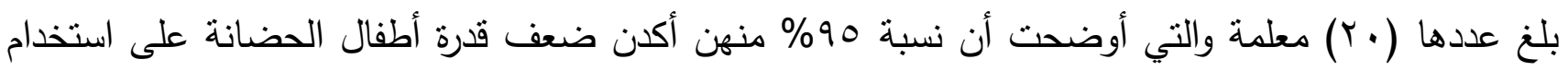

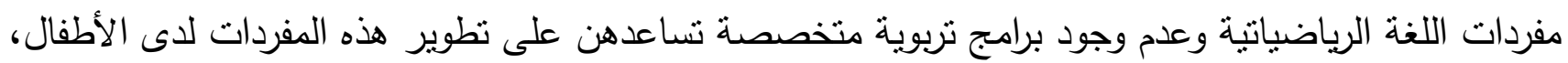

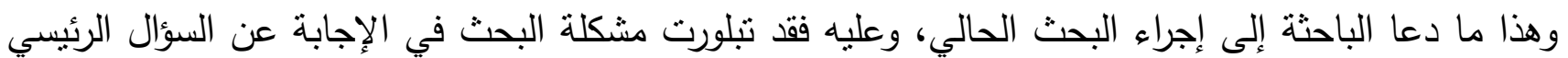
التالي:

ما فعالية برنامج قائم على أنشطة اللعب الموجه في تطوير اللغة الرياضياتية لاى طقل الحضانة ؟ ويتفرع من هذا السؤال الرئيسي الأسئلة الفرعية التالية:

ا ـ ما هي مفردات اللغة الرياضياتية التي يمكن تطويرها لدى طفل الحضانة ؟

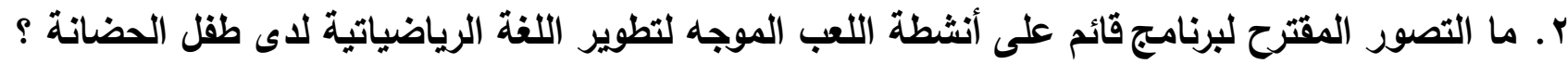

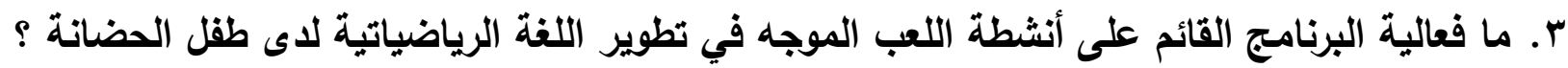

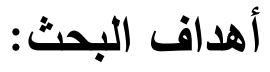

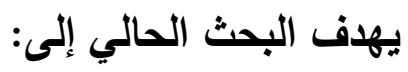

1 ـ إعداد قائمة ببعض مفردات اللغة الرياضياتية المناسبة لطفل الحضانة. r. تخطيط وبناء برنامج قائم على أنشطة اللعب الموجه لنطوير اللغة الرياضياتية لدى طفل الحضانة. r. بناء اختبار اللغة الرياضياتية المصور لاى طفل الحضانة. ع. قياس فعالية البرنامج القائم على أنشطة اللعب الموجه في تطوير اللغة الرياضيانية لدى طفل الحضانة. 
ا . يستمد البحث أهيته من أهمية المرحلة العمرية التي يتتاولها وهي مرحلة الحضانة من (ب-؟) سنوات.

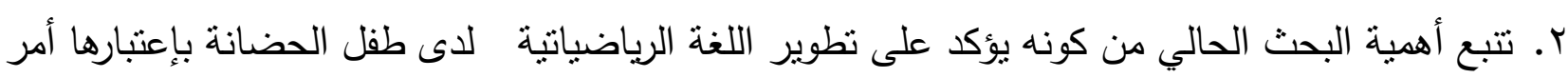
حيوي لنطوير اللغة عامة وتطوير الكفاءة الرياضياتية بشكل خاص. r. إلقاء الضوء على أهمية أنثطة اللعب الموجه كاستراتيجية هامة وممتعة في تعليم طفل الحضانة.

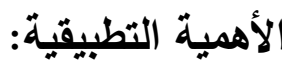

ا. لفت أنظار المسئولين بوزارة التضامن الإجتماعي إلى أهمية وضع برامج تربوية متخصصة مناسبة لأطفال الحضانة. r. إثراء المكتبة العلمية ببعض المقاييس الخاصة بمرحلة الحضانة يمكن أن تقيد الباحثين والمهتمين بدراسة تعلم وتقويم الطفل. r. يقدم البحث عددًا من أنشطة اللعب الموجه المقترحة لنطوير اللغة الرياضياتية لدى طفل الحضانة قد يستقيد منها مخططي المناهج ومعلمات الحضانة والوالدين. مصطلحات البحث:

طقل الحضانة Pre-school Child: هو الطفل الملتحق بالحضانة في المرحلة العمرية (ץ-؟) سنوات. (رانيا

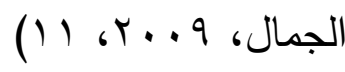
وتعرف الباحثة طفل الحضانة إجرائيًا في البحث الحالي بأنه: الطفل الذي يبلغ من العمر (ب-乏) سنوات وملتحق بالحضانة. اللعب الموجه Guided Play: هو التعلم بالاكتثاف وهو نهج وسيط بين التعليم المباشر واللعب الحر. (Fisher, K. R., et al, 2013, 1872)

وتعرف الباحثة أنشطة اللعب الموجه إجرائيًا في البحث الحالي بأنها: مجموعة من الأنشطة الحسية التي يقوم

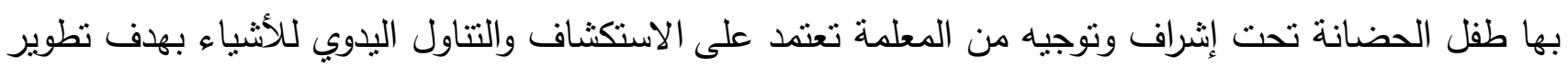
مفردات اللغة الرياضياتية لديه. اللغة الرياضياتية Mathematical Language: مفردات لغوية تساعد الطلاب على مواصلة نطوير مفاهيمهم الرياضياتية. (Riccomini, P. J., et al, 2015, 77) 
وتعرف الباحثة اللغة الرياضياتية إجرائيًا في البحث الحالي بأنها: مجموعة من المفردات اللغوية الرياضياتية

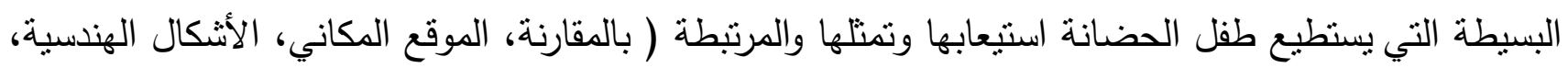

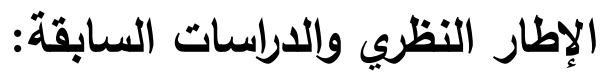
ويتناول هذا الجزء:

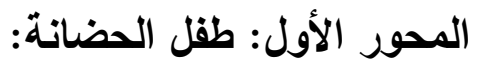

تتفاوت أعمار وقدرات أطفال الحضانة في هذه السن المبكرة التي لها خصائص نمو وحاجات تختلف عن

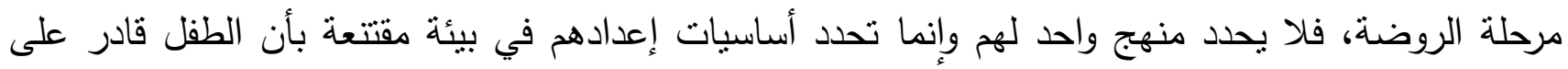

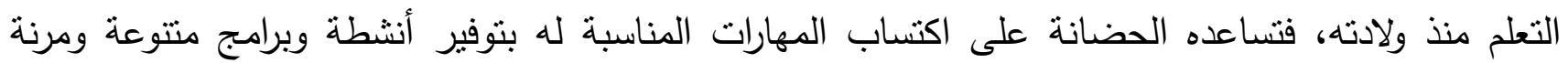

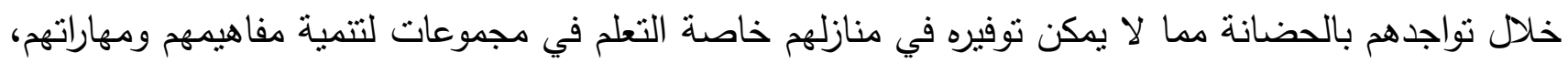

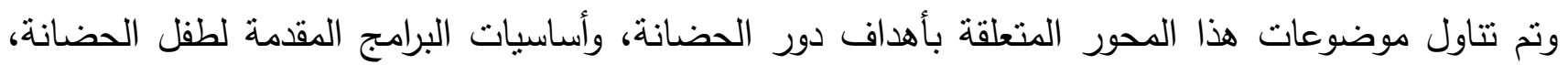

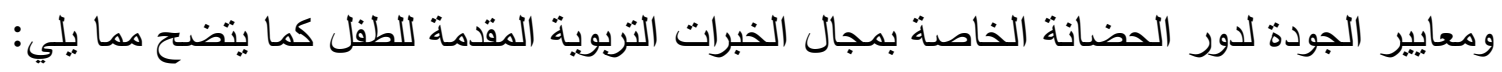

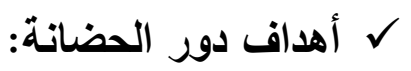

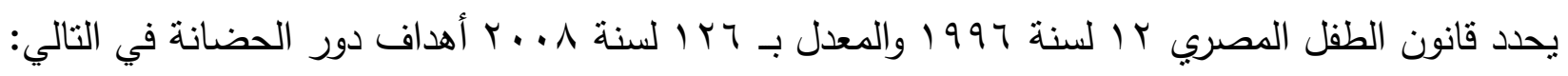
ا ـ ـ رعاية الأطفال اجتماعياً وتتمية مواهبهم وقدراتهم.

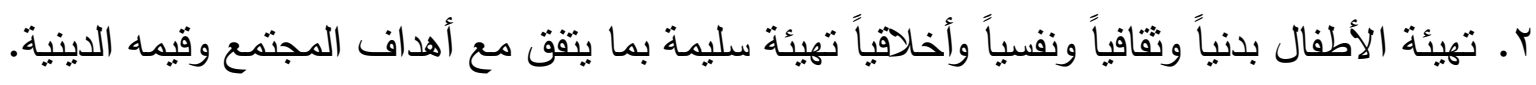
r. نشر الوعي بين أسر الأطفال لتنشئتهم تتشئة سليمة.

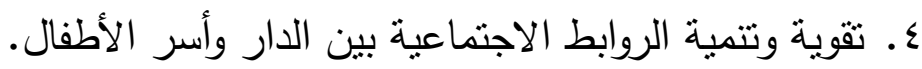

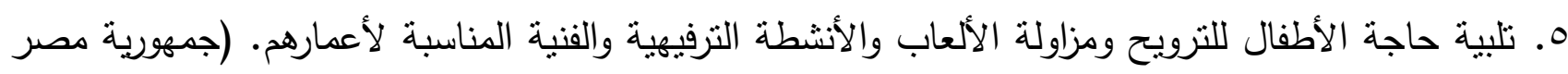

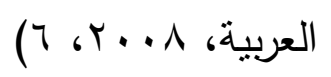

ل أساسيات البرامج التربوية والتعليمية في الحضانة:

الأساسيات التي تُنىى عليها البرامج التربوية والتعليمية في الحضانة متعددة تجملها "وزارة التتمية الاجتماعية"

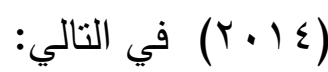

ا ـ يتعلم الطفل بشكل غير مباشر بعض الخبرات المعرفية في ممارسته للأنشطة الحركية والاجتماعية وغيرها. r. يكتسب الطفل اللغة من المربية وذلك بتحفيزه على التحدث واستخدام الكلمات والجمل التي يتخاطب بها يوميًا في حياته ، على أن يكون الحوار ذا هدف له علاقة بثقافة محددة مثل (النظافة، العمل الجماعي، عن الحيوانات الأليفة وغيرها) ، ويعامل كل طفل حسب فئة أنس عمره. 


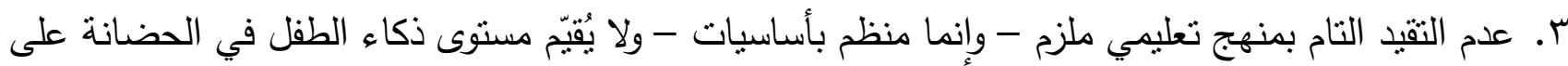

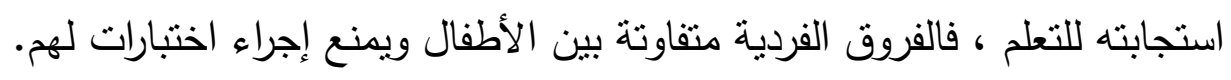

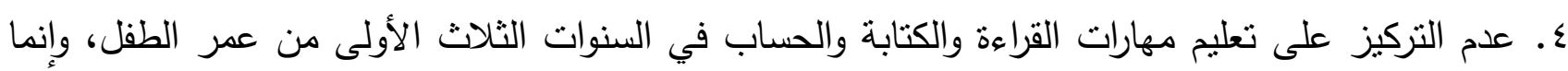

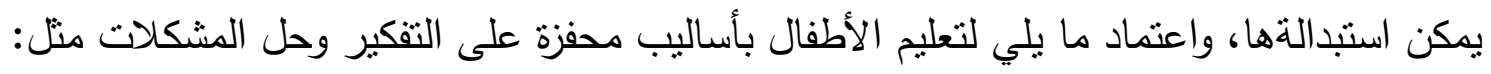

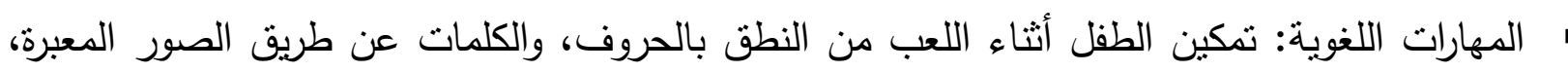

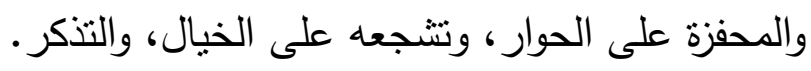

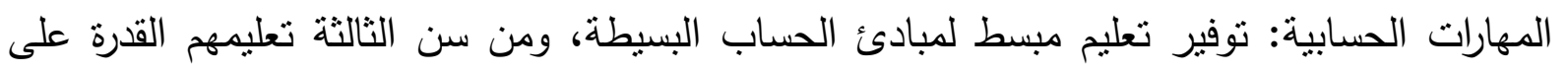

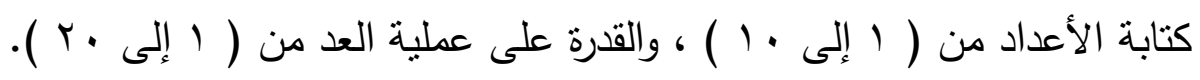

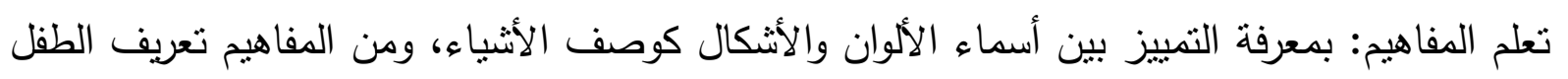

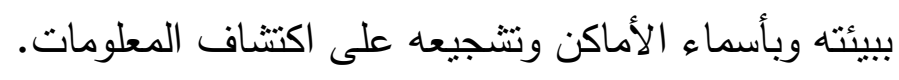

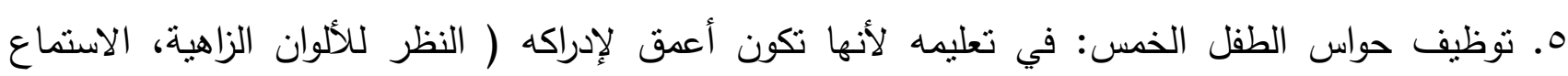

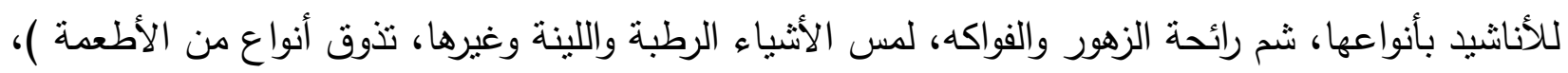
فيتعلم الطفل أسماء كل ذلك عن طريق حواسه.

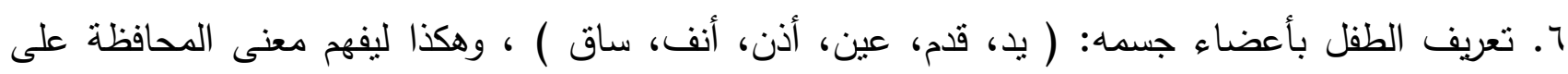

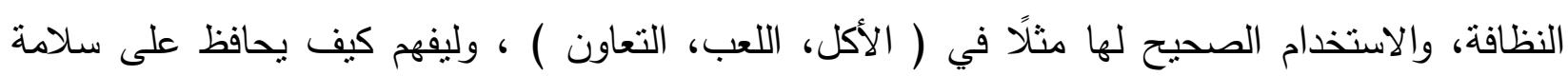
جسمه من المخاطر . (اعلماء. V. إعطاء الطفل مسئوليات في اللعب: تشعره بقيمة ذاته، وإبراز شخصيته، وتبعث في نفسه الثقة، وتجعله يفهر قدراته متل (حمل المكعبات الخفيفة، ترنيب زاوية اللعب، حفظ الألعاب في الجزء المخصص لهاء لهاب من الخزانة

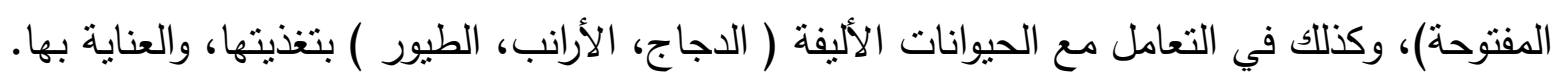

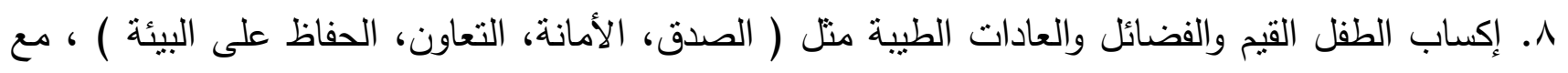

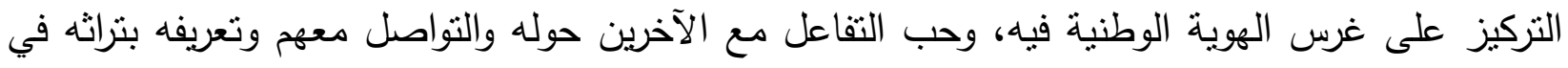
أنشطة المناسبات. 9. الأنشطة التعليمية باستخدام الأدوات والاجهزة والوسائل التعليمية مثل: ألعاب حركية بالموسيقى والأناشيد.

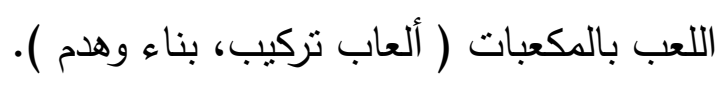
القصص المسموعة والمرئية. اللعب في ركن أنشطة الخيال، والتسلق، والمراجيح، وألعاب أخرى. الاهتمام بالرسم، والتلوين كوسيلة من وسائل التعبير عن اهنماماته، وات الطفل، وعلافته بمن حوله

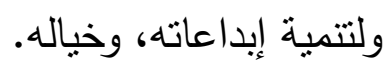


• ا.إكساب الطفل خبرات حياتية ميدانية جديدة: بتتظيم الرحلات، والزبارات لأماكن مخطط لها كموقع تعليمي

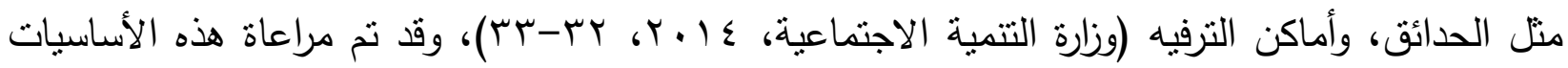

$$
\text { عند بناء برنامج البحث الحالي. }
$$

ل معايير الجودة لاور الحضانة الخاصة بمجال الخبرات التريوية للطقل:

حددت "وزارة التأمينات والثُؤن الاجتماعية" (11 ـ ץ) معايير الجودة لدور الحضانة الخاصة بمجال الخبرات التريوية للطقل والتي تم في ضوئها تخطيط برنامج البحث الحالي، وهي كالتالي: المعيار الأول - اكتساب مفاهيم ومهارات تتمي اللغة:

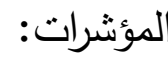

ا . ينمى لدى الطفل مهارات الحوار والحديث والإصغاء. Y. ت تمية بعض مفردات اللغة. r. يتمكن من نطق مفردات اللغة بشكل صحيح. ع. يكتسب قواعد اللغة بشكل مبسط (هو للمذكر ، هي للمؤنث، .....). 0. نمو مهارات نطق الأعداد من (1- . (1). 7. يتعرف على الكلمات المصحوبة بالصور .

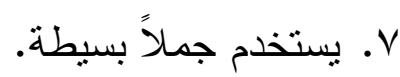
المعيار الثاني_ ممارسة الفنون: المؤشرات:

ا ـ يتعرف الطفل على الأدوات والخامات الفنية المتاحة. r. يميز بين بعض الألوان.

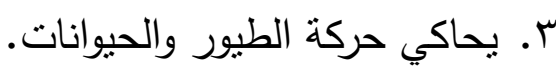
ـ. يمارس حركات إيقاعية منل الرقص. ه. يردد ما يستمع إليه من أغاني وأناشيد. 7. يحاكي بعض الإيقاعات الموسيقية (النقر ، الدبدبة، ...). V. يميز بين أصوات الآلات الموسيقية. ^. يبدع من خلال اللعب الحر والرسم والتشكيل بالعجائن. المعيار الثالث- ترسيخ مفاهيم اجتماعية بناءة: المؤشرات:

ا . يميز الطفل بين الجنسين (ولد-بنت). r. يثنارك في المناسبات الاجتماعية (أعياد الميلاد، عيد الأم، ....). 
r. ينمي لايه مشاعر الانتماء ومفاهيمها. ع. يتقمص بعض الثخصيات (الطبيب، الضابط، ....). ه. تتمية مهارات فن التعامل مع الآخرين (إلقاء التحية، الاستئذان، الاعتذار، ـ .....). T. بكتشف البيئة من حوله (منزله، مدرسته، ....).

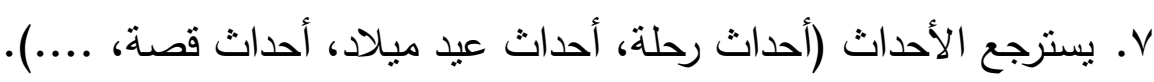

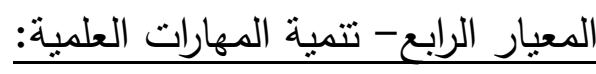

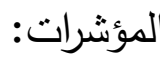

1. يعد الطفل الأرقام من (1- • (1) على أن يكون لهذه الأرقام مدلولاتها.

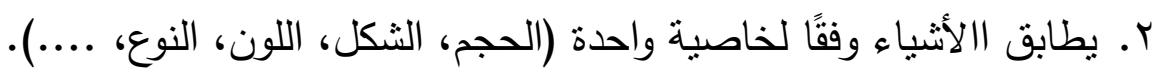
r. يصنف الأثياء وفقًا لخاصية واحدة (مثلثات، مربعات، .....). ع. يمارس عملية التسلسل البسيط للأشياء. ه. يستطيع ملاحظة ظواهر الحياة اليومية (متل شروق الثمس). 1. يستطيع التعرف على خـواص الأثـياء (اللمس، الطعم، الرائحسة، اللـون، ....). (وزارة التأمينـات والثـئون

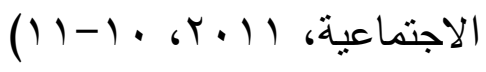
المحور الثاني: اللغة الرياضياتية:

تطوير المفاهيم والمهارات الرياضياتية يبدأ في السنوات الأولى من حياة الأطفال، حيث يينون أفكارهم حول

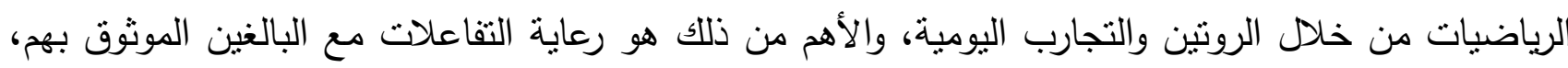
حيث تعتبر اللغة جانب رئيسي في هذه التفاعلات، قيجب تنكيل وتوجيه الدحادنات باستخدام اللغة لمساعدة الأطفال على مواصلة تطوير مفاهيمهم الرياضياتية.

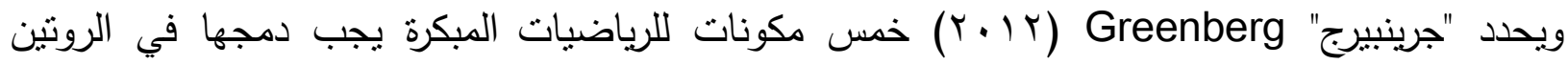
اليومي للرضع والأطفال الصغار هي: الأرقام والعمليات، الأثكال والعلاقات المكانية (الهندسة)، القياس، الأنماط

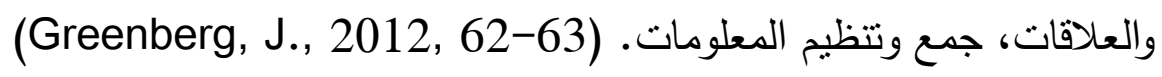

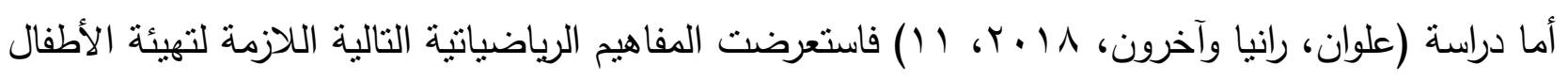
في مرحلة الطفولة المبكرة وهي: العلاقات المكانية، علاقات الترتيب، المفاهيم الهندسية، مفاهيم ما قبل العدد، التيات

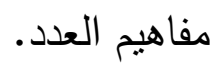
ويتعلم الأطفال الرياضيات واللغة في تقدم مماتل، بدءًا من مرحلة الطفولة تتطور مهارات اللغة مع مرور الوقت حيث ييني الأطفال مفرداتهم وطول الجمل وتعقيد الجملة، ويتعلم الأطفال كيفية التعبير عن أفكارهم بالكلمات عن طريق بناء المفردات الخاصة بهم وفهمهم لقواعد اللغة وقدرتهم على استخدام جمل أطول وأكثر

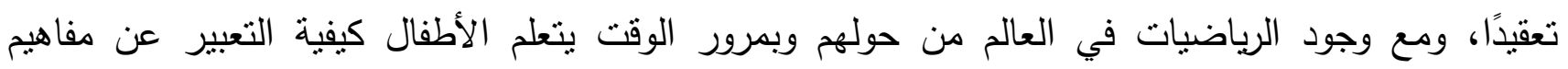


(Harris, B., Petersen, D., 2019, الرياضيات الأكثر تعقيدًا والتي تتطوي على القياس والهندسة والمنطق

كما يتعلم الأطفال الصغار أيضًا أنواعًا أخرى من مفردات اللغة الرياضياتية مثل أسماء الأشكال ("مربع")

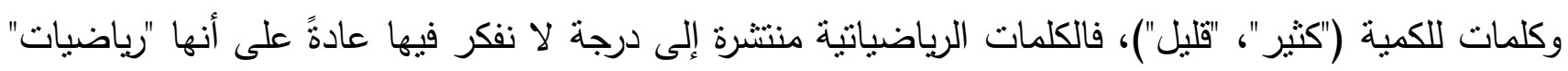

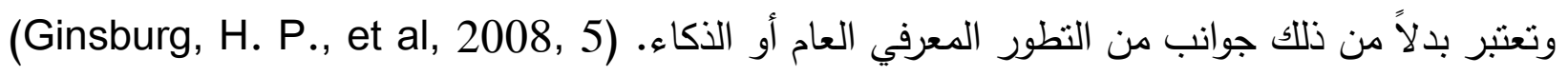

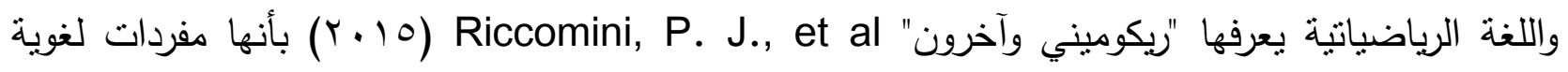

تساعد الطلاب على مواصلة تطوير مفاهيمهم الرياضياتية. (Riccomini, P. J., et al, 2015, 77) فعلى المعلمين في الفصول الدراسية للرضع والأطفال الصغار المشاركة في المزيد من مفردات اللغة النة الرياضياتية وخاصة المتعلقة بالعلاقات المكانية والقياس. (Rudd, L. C., et al, 2008, 80)

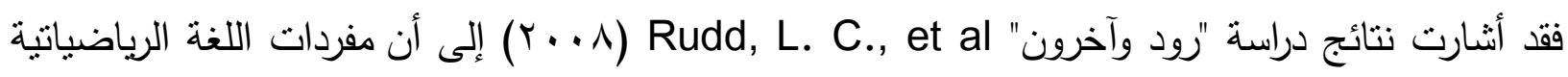

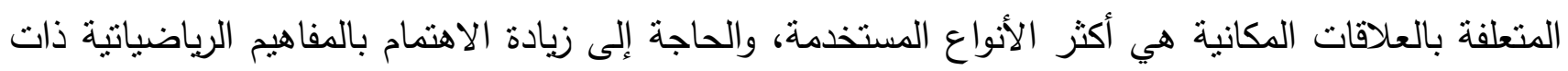
المستوى الأعلى والتي يتم استكثافها في إعدادات الطفولة المبكرة.

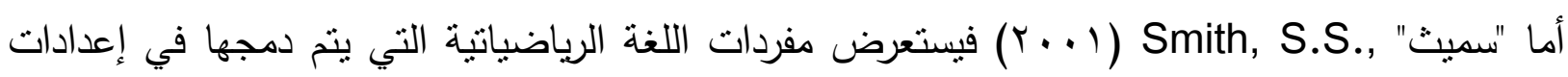
الطفولة المبكرة لتشمل: 1. كلمات المقارنة: ( كبير/صغير -كثير/قليل- طويل/قصير -سريع/بطئ- نقيل/خفيف- ساخن/باردعالي/منخفض- قريب/بعيد ). r. كلمات الموقع المكاني: ( داخل/خارج - فوق/تحت - يمين/يسار - أمام/خلف- - بعيد/قريب- قمة/قاع ).

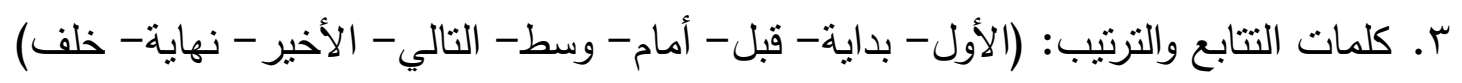
ع. كـة لغة الوقت وتتشم:

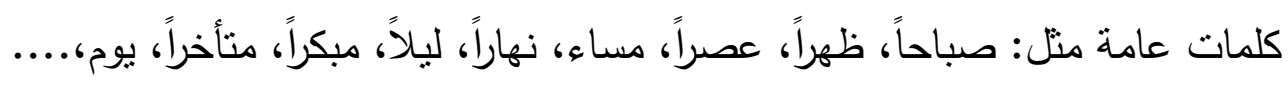

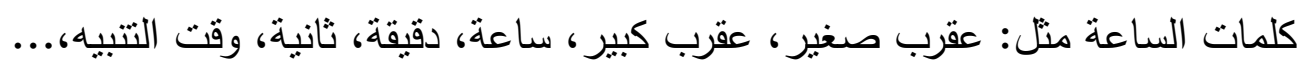

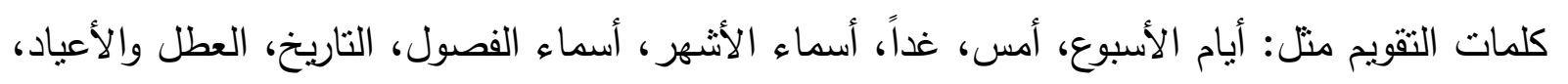

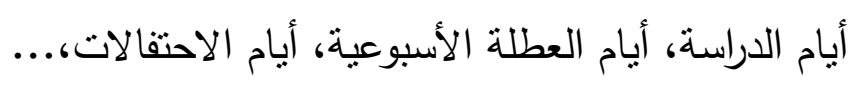

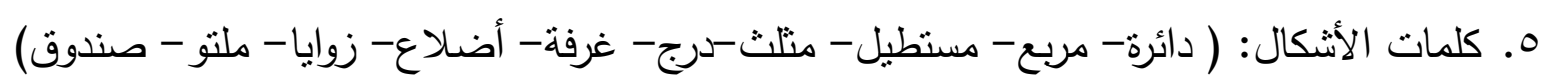

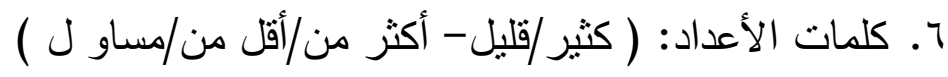
V. الرموز الرياضياتية وتتشمل:

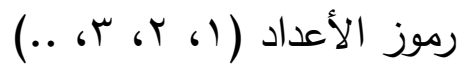

$$
\begin{aligned}
& \text { رموز العلاقات (=، ...) } \\
& \text { رموز العمليات (+، -، ... (+) }
\end{aligned}
$$


A. العبارات الرياضياتية: وتتشمل عبارات العمليات الحسابية البسيطة منل الجمع والطرح. (Smith, S.S., $.2001,22-32)$

وقد تضمنت قائمة مفردات اللغة الرياضياتية لطفل الحضانة في البحث الحالي جميع هذه المفردات بهدف تحديد أهم مفردات اللغة الرياضياتية التي يمكن تطويرها لدى طفل الحضانة.

المحور الثالث: تطوير اللغة الرياضياتية خلال أنثطة اللعب الموجه:

يعتبر اللعب مدخلاً أساسيًا لنمو الطفل عقليًا ومعرفيًا وإجتماعيًا وإنفعاليًا، فمن خلاله يبدأ الطفل بمعرفة الأشياء وتصنيفها ويتعلم مفاهيمها ويعمم فيما بينها على أساس لغوي، فهو الأساس في بناء المعرفة لدى الطفل

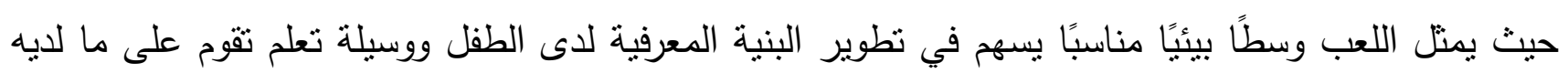
من إمكانات وقدرات.

ويعرف الهويدي، زيد (Y Y (Y) اللعب بأنه نثاط هادف يتضمن أفعالاً تقوم بها المعلمة أو مجموعة الأطفال

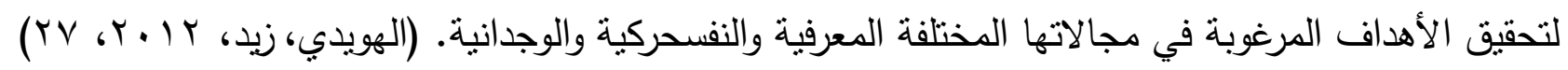
فاللعب إذن نشاط موجه يقوم به الأطفال لتتمية سلوكهم وقدراتهم العقلية والجسمية والوجدانية، ويحقق في نفس

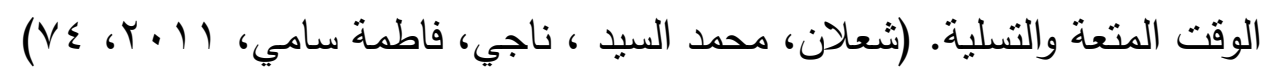
أما الصوالحة، محمد (10 ب ب) فيعرف اللعب بأنه نشاط حر موجه أو غير موجه غايته الاستمتاع ويكون على

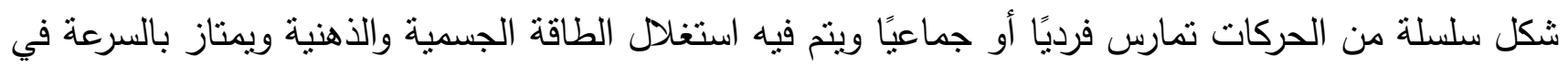

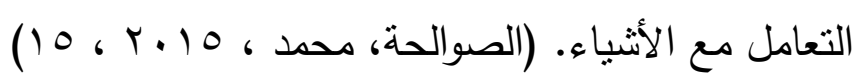

$$
\begin{aligned}
& \text { ومن أهم فوائد اللعب ما يلي: }
\end{aligned}
$$

1. اللعب أداة تربوية ووسيلة تساعد في إحداث تفاعل الطفل مع عناصر البيئة ومكوناتها لغرض تعلمه وإنماء شخصيته وسلوكه، فهو يمتل وسيلة تعليمية تقرب المفاهيم إلى الأطفال وتساعدهم في إدراك معاني الأشياء

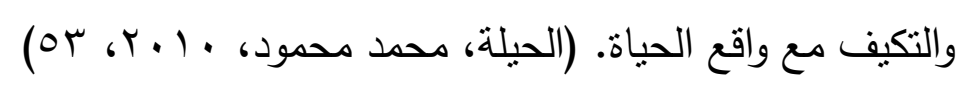

r. يساعد في تتمية مهارة الاكتشاف وتجميع الأثشياء وفكها وتركيبها لادى الطفل. r. يفسح المجال للطفل لكي يتعلم الكثبر، فهو يتعرف على الأنكال والألوان والأحجام ومهارات التصنيف ويحصل على خبرات كثيرة لا يتمكن من الحصول عليها من مصادر أخرى. ع. يمنح الفرصة للطفل لإستخدام حواسه وعقله وزيادة قدرته على الفهم. 


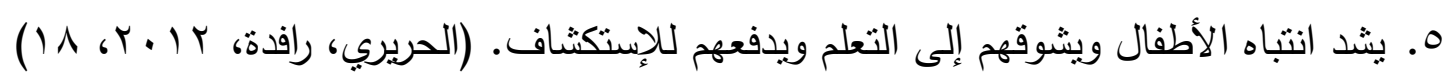

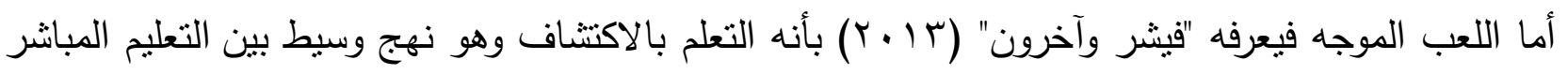
واللعب الحر. (Fisher, K. R., et al, 2013, 1872) ومن فوائد اللعب الموجه ما يلي:

ا . يقع اللعب الموجه في منتصف الطريق بين التعليم المباشر واللعب الحر . r. يخلق مواقف تعلم تشجع الأطفال على أن يصبحوا شركاء نشطين ومشاركين في عملية التعلم. r. أنشطة اللعب الموجه ممتعة، طوعية، مرنة، تتطوي على مشاركة نشطة. ع. يمكن للمعلمين تعزيز استكثاف الأطفال وتعلمه من خلال التعليق على اكتشافاتهم أو مشاركتهم في اللعب أو طرح أسئلة مفتوحة حول ما يجدونه. ๑. هناك تعاون بين المعلم والطفل مع اعتبار اهتمامات الطفل في المقدمة. 7. يشجع على تعلم المهارات الرياضيانية والمكانية. (107-S., et al, 2013, 105) V. يزيد من المشاركة والاستكثاف المباشر حيث يبني الأطفال المعرفة بنشاط عندما يستكثفون بيئتهم ويتفاعلوا (Fisher, المها، فبرامج التعلم المرحة المرتكزة على الطفل تعزز الأداء الأكاديمي مقارنة بالبرامج الأكاديمية.

K. R., et al, 2013)

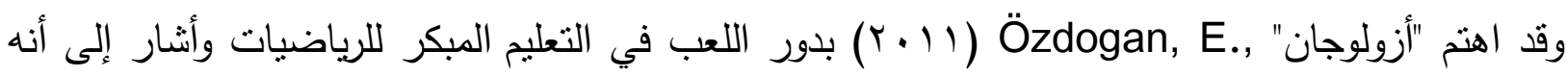

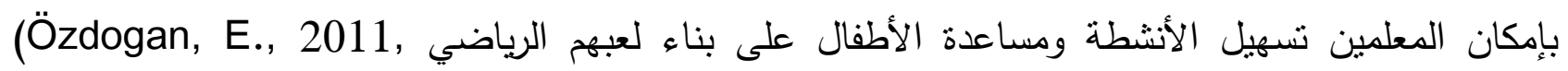
(3120، فالعديد من مهارات الرباضيات تحتاج إلى أن يتم تقديمها من خلال الأنشطة والألعاب المرحة في مناهج التعليم المبكر (Geetha R. B., \& Eason, S. H., 2015, 28)، حيث يوفر المعلمون فرصًا دورية لإعادة انخراط الأطفال في مجموعة منتوعة من الأنشطة لمساعدتهم على تطوير وإثراء معرفتهم، فبدون فرص المزيد من المشاركة لن يكتسب الأطفال الفهم العميق المطلوب من أجل التفكير والتواصل الرياضي.

(Riccomini, P. J., et al, 2015, 239)

وعندما يركز المعلمون على لغة الرياضيات ويعرضون المفاهيم الرياضياتية في جو من المرح وطرق الانخراط يكون الأطفال متحمسين لتعلم المفاهيم التي تتجاوز ما هو منوقع عادة من سنهم. Rudd, L. C., et) al, 2008, 77) حيث يستكثف الأطفال الصغار الرياضيات عندما يلعبون ويبنون الأبراج بالحواجز، فيقومون بفرز الكتل حسب الحجم واللون ويلاحظون العلاقات المكانية ويطورون مهارات التفكير، بينما يتعلمون الأشكال التي يمكن بالترن وضعها فوق بعضها البعض - أي الأشكال سوف تطيح بالبرج الذي قاموا ببنائه - وكيفية دمج الأشكال مع (Harris, B., إنشاء تكوينات مألوفة، فيقوم الأطفال بمقارنة الأشياء أثثاء اللعب واستكثاف الأنماط والأشكال

Petersen, D., 2019, 2) 
فقد هدفت دراسة "كوهين وايمونز" Cohen, L. E. \& Emmons, J. (7 • ( إ) إلى التحقق من

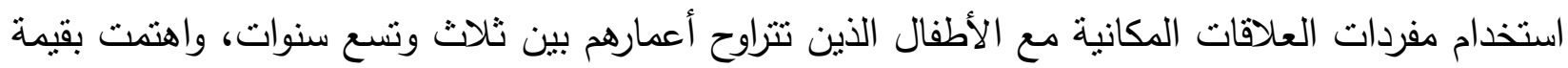

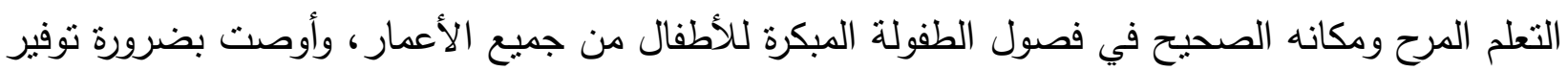

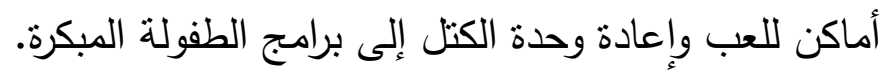

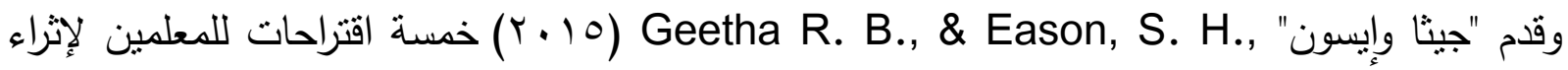
قاعات النشاط بالمزيد من أنشطة الرياضيات المرحة، وقد تم الآخذ بمعظمها في برنامج البحث الجالي

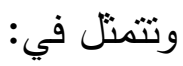
1. البحث عن مناهج مرحة: فبالإضافة إلى دمج أنشطة اللعب الفردية في قاعة النشاط، ظهرت مناهج أكثر شمولاً لتحسين المعرفة الرياضياتية لمرحلة الحضانة ورياض الأطفال التي تضمن آثناًً إيجابية للعب أيضًا.

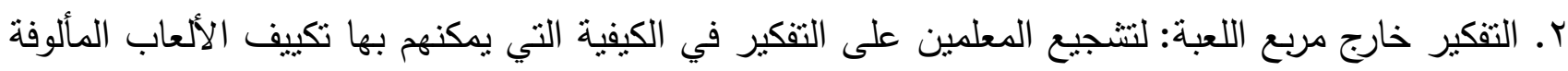
للتأكيد على معايير الرياضيات الأساسية. r. حديث المعلمين عن الرياضيات أثناء اللعب وكذلك أثناء الأنشطة في المجالات الأخرى: فمن المرجح أن يرغب الأطفال في المشاركة في أنشطة الرياضيات عندما يرون أن ذلك مفيد بالنسبة لما يشاركون فيه.

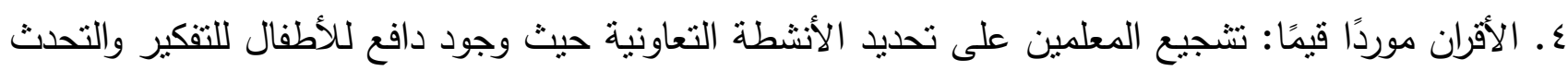

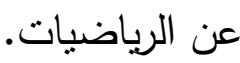
ه. إثراك أولياء الأمور : يمكن للمعلمين مساعدة الآباء على إيجاد طرق لإثراك الأطفال في أنثطة الرياضيات المرحة التي تكمل المناهج الدراسية. (Geetha R. B., \& Eason, S. H., 2015, 30-32)

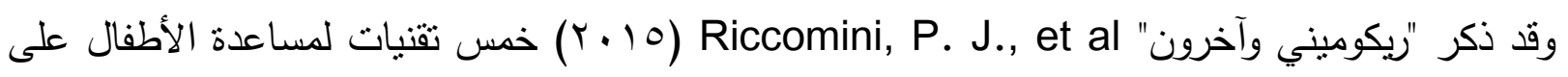

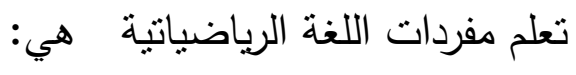

$$
\begin{aligned}
& \text { 1. تُعليم الدفردات بشكل صريح. } \\
& \text { r. استراتيجية ذاكرتي. } \\
& \text { r. التعرض المتكرر لمفردات رياضية جديدة. } \\
& \text { ع. أنشطة اللعب. }
\end{aligned}
$$

ه. النطبيقات التكنولوجية، حيث تنيح استخدام هذه الثقنيات فرصًا لنطوير مفردات اللغة الرياضياتية بطريقة

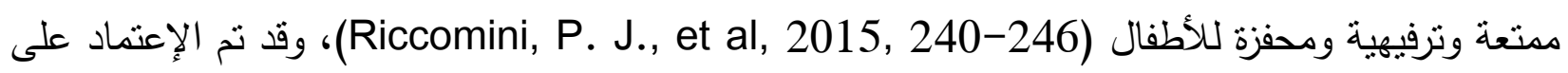
معظمها في برنامج البحث الحالي، كما تم الاعتماد على الألعاب التالية:

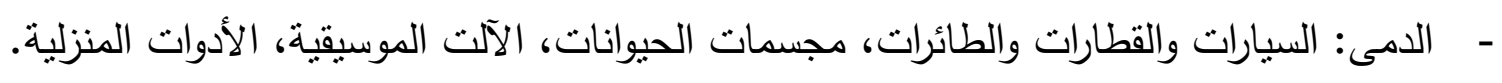
-

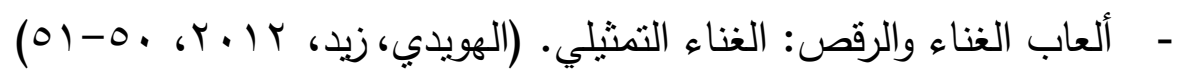




\section{فروض البحث:}

ا ـ توجد فروق دالة إحصائيًا بين متوسطات درجات أطفال المجموعة التجريبية في القياسين القبلي والبعدي على "اختبار اللغة الرياضياتية المصور لطفل الحضانة" في اتجاه القياس البعدي.

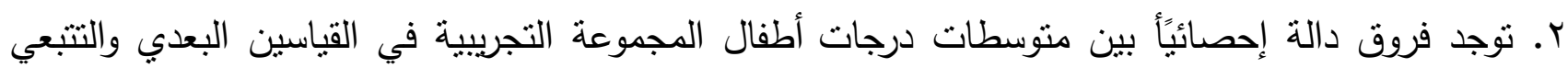
على "اختبار اللغة الرياضياتية المصور لطفل الحضانة" في اتجاه القياس التتبعي. خطوات وإجراءات البحث الميدانية: تتمثل في الإجراءات المنهجيـة المتبعـة في البحث وتتـمل: المنهج والأدوات المستخدمة والتجربـة الميدانيـة وكذلك الأساليب الإحصائية لمعالجة البيانات.

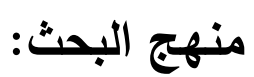

اتبع البحث الحالي المنهج شبه التجريبي الذي يعتمد على التصميم التجريبي القائم على المجموعة الواحدة،

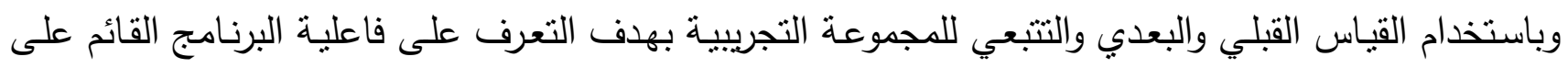
أنشطة اللعب الموجه (كتغير مستقل) ومدى مساهته في تطوير اللغة الرياضياتية لدى طفل الحضانة من ب- ــ سنوات (كمتغير تابع)، لمناسبته لطبيعة البحث والفئة العمرية.

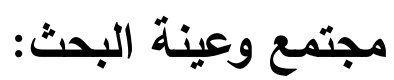

يتمثل مجتمع البحث الحالي في جميع الحضانات الأهلية والحكومية بمحافظة الفيوم، وتمثلت عينة البحث

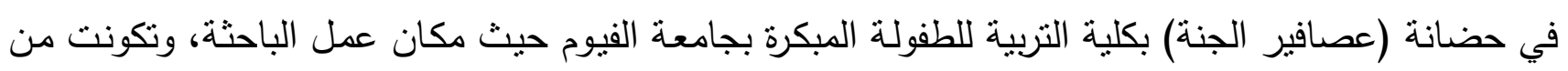

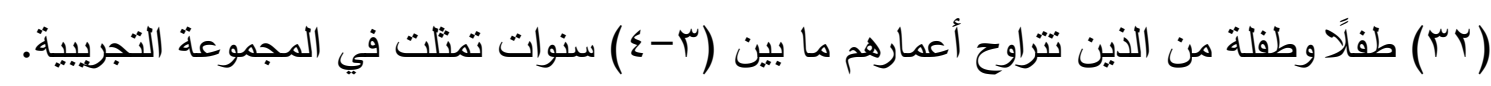
وقد راعت الباحثة عند اختبارها للعينة ما يلي: لئي:

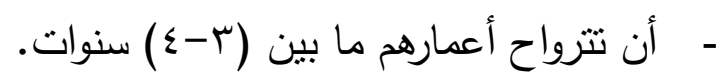
- أن يكونوا من الملتزمين بالحضور في الحضانة.

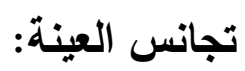
• ثامت الباحثة بإيجاد دلالة الفروق بين متوسطات درجات أطفال المجموعة التجريبية في القياس القبلي من جدول (1) (1)

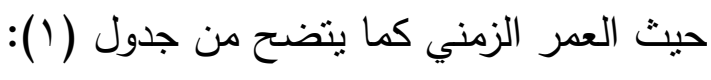

دلالة الفروق بين متوسطات درجات أطفال المجموعة التون التجريبية

\begin{tabular}{|c|c|c|c|c|c|}
\hline \multicolumn{2}{|c|}{ حدود الدلالة } & \multirow[t]{2}{*}{ درجة حرية } & \multirow[t]{2}{*}{ مستوى الدلالة } & \multirow[t]{2}{*}{ SL } & \multirow[t]{2}{*}{ المتغيرات } \\
\hline$\because .0$ & $\because \cdot 1$ & & & & \\
\hline TI & Y..Y & IT & غير دالة & $\varepsilon .77 \wedge$ & العمر الزمني بالثهور \\
\hline
\end{tabular}


يتضح من جدول (1) عدم وجود فروق دالة إحصائيًا بين منوسطات درجات أطفال المجموعة التجريبية في

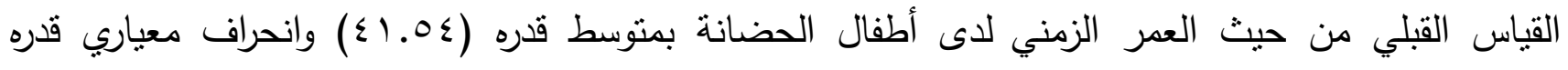
(ب.0r) مما يشير إلى تجانس أطفال المجموعة التجريبية.

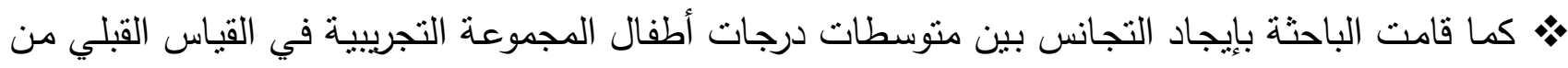
حيث اللغة الرياضياتية كما يتضح من جدول (r): جدول (r) (r) (Y)

دلالة الفروق بين متوسطات درجات أطفال المجموعة التجريبية

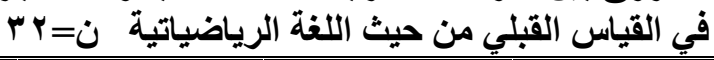

\begin{tabular}{|c|c|c|c|c|c|}
\hline \multicolumn{2}{|c|}{ حدود الدلالة } & \multirow{2}{*}{ درجة حرية } & \multirow{2}{*}{ مستوى اللالالة } & \multirow[t]{2}{*}{ SL } & \multirow{2}{*}{ المتغيرات } \\
\hline. .0 & $\because .1$ & & & & \\
\hline$\overline{V . \wedge}$ & $11 . r$ & $r$ & غير دالة & 0.879 & اللغة الرياضياتية \\
\hline
\end{tabular}

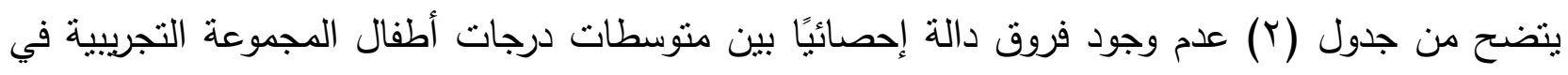

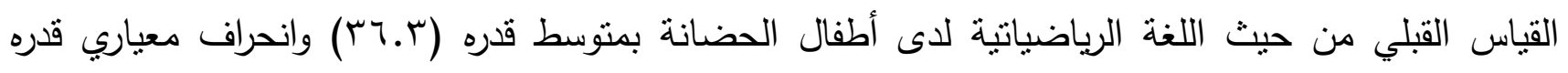
(1.01) مما يشير إلى تجانس أطفال المجموعة التجريبية. حدود البحث: الحدود المكانية والبشرية: اقتصرت الحدود المكانية على أطفال حضانة (عصافير الجنة) بكلية التربية للطفولة

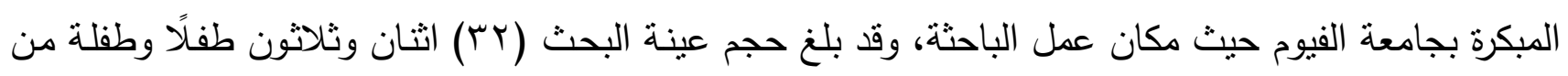

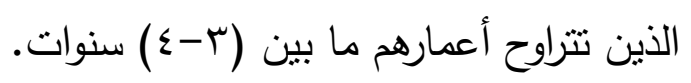

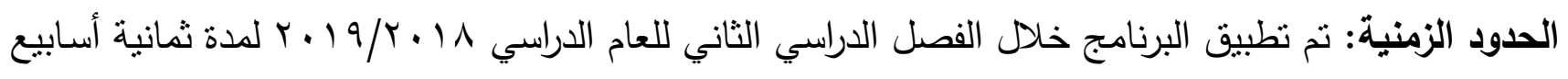
متصلة بواقع يومين اسبوعيًا. الحدود الموضوعية: اقتصر البحث الحالي على مفردات اللغة الرياضياتية ( المقارنة، الموقع المكاني، الأثكال الهندسية، الزمن ) بناءًا على استطلاع رأي المحكمين ومناسبتها لمستوى تفكير أطفال الحضانة. أدوات البحث:

ا ـ قائمة مفردات اللغة الرياضياتية لطفل الحضانة. (إعداد الباحثة) r. برنامج أنشطة اللعب الموجه لتطوير اللغة الرياضياتية لدى طفل الحضانة ـ (إعداد الباحثة) r. اختبار اللغة الرياضياتية الدصور لطفل الحضانة. (إعداد الباحثة)

\section{وفيما يلي وصف تفصيلي لأدوات البحث:}

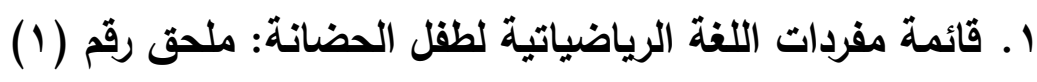

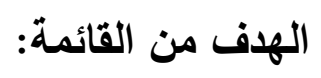

تهدف القائدة إلى تحديد أهم مفردات اللغة الرياضياتية التي يمكن تطويرها لدى أطفال الحضانة بإعتبارها أمرًا حيوًا لنطوير اللغة عامة وتطوير الكفاءة الرياضياتية بشكل خاص. 
خطوات إعداد القائمة:

تم تصميم القائمة وفقًا للخطوات الثالية: - الإطلاع على بعض المراجع العربية والأجنبية والدراسات والبحوث التي اهتمت بمجال البحث منها: "سميث"

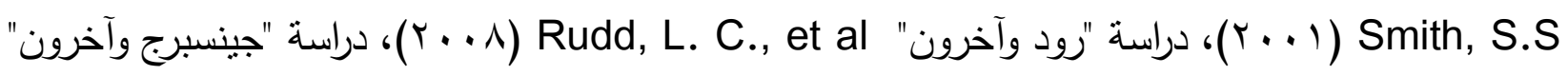
(Y. Greenberg, J., " Ginsburg, H. P., et al,

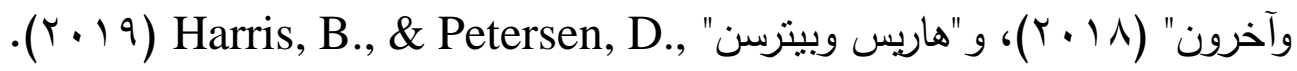
- - إعداد قائمة بمفردات اللغة الرياضياتية التي يمكن تطويرها لدى طفل الحضانة، واشتملت القائمة في صورتها

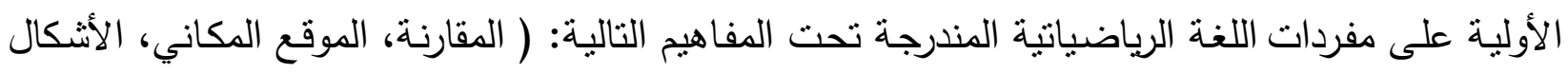

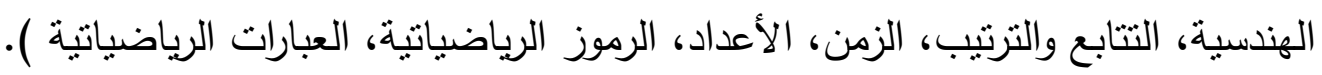

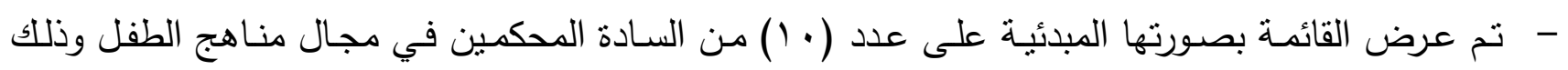

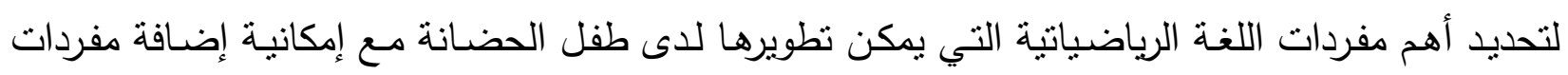

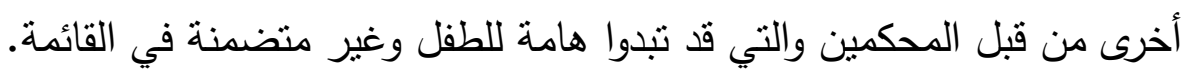
- تدرجت مستويات القياس تحت ثلاث مستويات: (هامة جدًا - منوسطة الأهمية- قليلة الأهمية). - مقد تم حساب نسبة الإتفاق بين المحكمين وتضدنت القائمة مفردات اللغة الرياضياتية التي تزيد نسبة الإتفاق

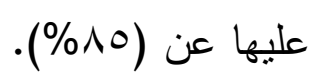
- تضمنت القائمة في صورتها النهائية بعض مفردات اللغة الرياضياتية والخاصة بالمفاهيم التالية: ( المقارنة، الموقع المكاني، الأثكال الهندسية، الزمن ) والتي يمكن تطويرها لدى طفل الحضانة، وبذللك قد تم الإجابة

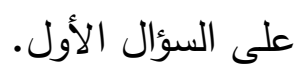

r • برنامج أنشطة اللعب الموجه لتطوير اللغة الرياضياتية لدى طقل الحضانة: ملحق رقم (r)

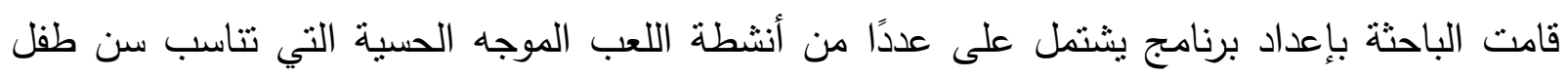
الحضانة من (r-؛) سنوات بهدف نطوير اللغة الرياضياتية لدى طفل الحضانة، وفيما يلي وصفاً مفصلًا للبرنامج:

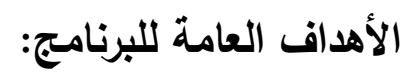
ا ـ إدراك مفردات المقارنة. r. تصنيف الأثياء طبقًا لمفردات المقارنة. r. الثعور بالمتعة أثثاء استخدام الأثشياءوالأدوات. ع. المشاركة في القيام ببعض المهام المحببة إليه. ه. إدرالك مفردات الموقع المكاني. 7. تحديد موقع الأثياء طبقًا لمفردات الموقع المكاني. 
V الاستمتاع بتشكيل الصلصال والعجائن. ^. التعرف على الأثنكال الهندسية. 9 ه. إعطاء أمنلة لبعض الأشياء فى البيئة تثبه الأثكال الهندسية. • ا. التذوق الجمالي للنثابه بين أثياء من البيئة والأثكال الهندسية.

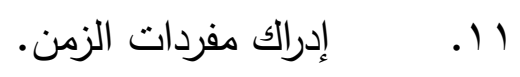
r ا. . التعرف على مظاهر الحياة بالنهار وبالليل. با ا. ترتيب أحداث الروتين اليومي حسب توقيتها (صباحًا، ظهرًا، مساءًا). ع 1. الوعي بأهمية مفردات الزمن لوصف الأحداث. 10. الثعور بالمتعة أثناء تمثيل أحداث الروتين اليومي.

الأهداف السلوكية للبرنامج: انتمل البرنامج على مجموعة من الأهداف المعرفية والحسحركية والوجدانية تصدرت كل نشاط والتي من

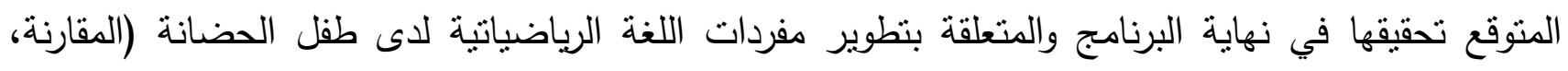
الموقع المكاني، الأشكال الهندسية، الزمن). الفلسفة التريوية للبرنامج:

انبتقت الفلسفة التربوية للبرنامج الحالي من نظريات وآراء بعض الفلاسفة والمفكرين المهتمين بمرحلة الطفولة

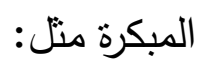
1. فلسفة منتسوري: التي اهتمت باللعب من خلال تدريب الحواس كمدخل لتعليم الأطفال وتهيئة البيئة بالوسائل

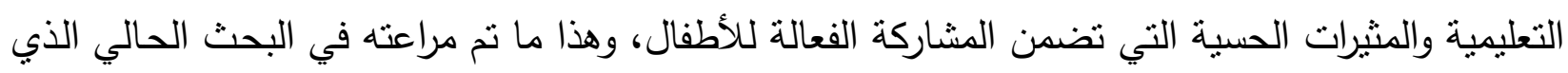

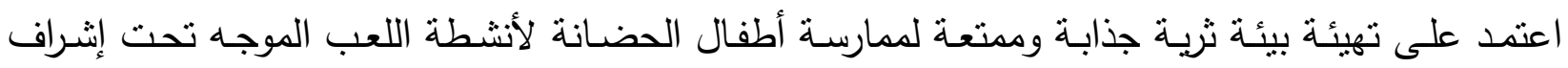
الباحثة والمعلمات.

r. فلسفة جون ديوي: الذي أكد على تعلم الأطفال الصغار من خلال الخبرة والعمل الباشر والاحتكالك بالبيئة

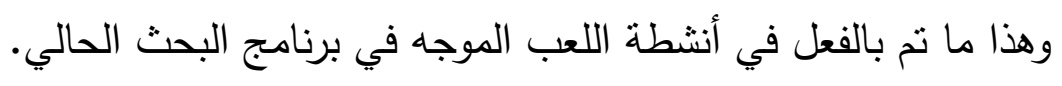

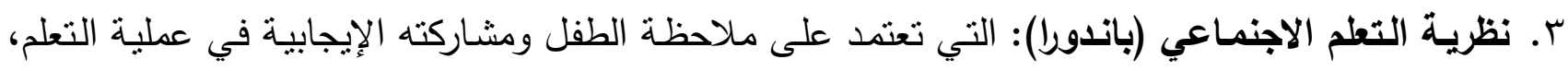

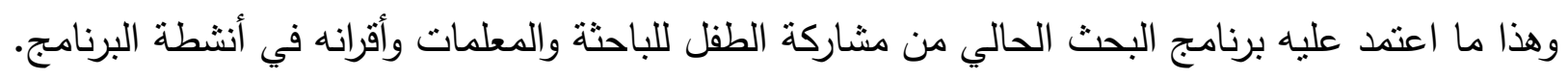

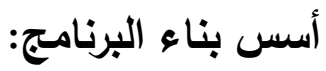
تم بناء برنامج البحث الحالي استتادًا إلى مجموعة من الأسس منها: إمباء ا ـ أن تتتاسب أنشطة البرنامج مع خصائص نمو أطفال الحضانة وميولهم وقدراتهم. r. أن تكون أنشطة البرنامج مشوقة وممتعة لأطفال الحضانة. 
r. أن تركز أنشطة البرنامج على استخدام الأطفال لجميع حواسهر. ع. مراعاة التندج من السهل إلى الصعب في أنشطة البرنامج. ه. مراعاة التسلسل المنطقي في أنشطة البرنامج.

7. تشجيع الأطفال على ممارسة الأنشطة بصورة فردية أو جماعية. V. إحتواء البرنامج على مجموعة من الألعاب والأنشطة التي تسهم في تتمية الإبتكار والإبداع لاى الأطفال. ^. نوافر عوامل الأمن والسلامة بالنسبة للأدوات والخامات والأجهزة المستخدمة في البرنامج. 9. التتوع في الوسائل التعليمية المستخدمة.

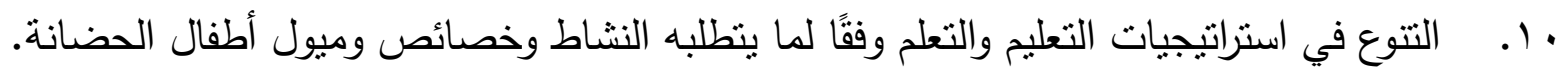
ال المتخدام أساليب تقويم مناسبة ومنتوعة. \$ محتوى البرنامج: تضمن البرنامج مجموعة من أنشطة اللعب الموجه بلغ عددها (rr) نشاطًا توزعت في أربع وحدات رئيسية

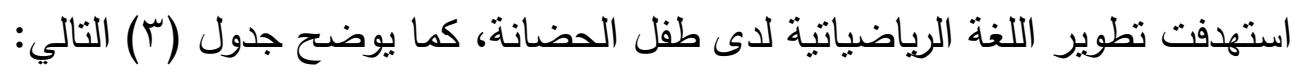
جدول (ए)

محتوى البرنامتج

\begin{tabular}{|c|c|c|c|c|}
\hline الأنثطة & اسم النشاط & مفردات اللغة الرياضياتية & وحدات البرنامج & a \\
\hline 1. & 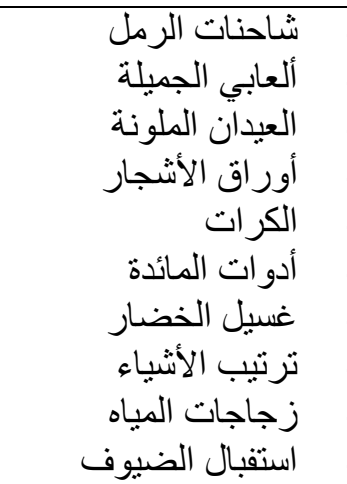 & 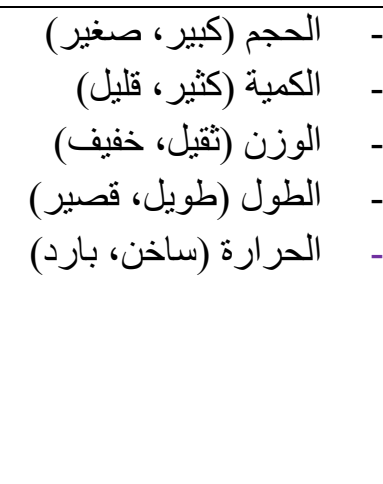 & مفردات المقارنة & .1 \\
\hline$\Lambda$ & 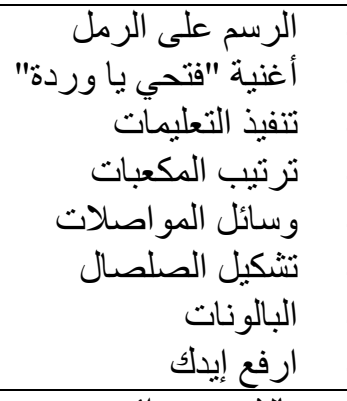 & - & مفردات العلاقات الدكانية & . \\
\hline$\Lambda$ & تيالا تيكيل أثنياء دمدورة & مربيع مائرة & مفردات الأشكال الهندسية &.$\Gamma$ \\
\hline
\end{tabular}




\begin{tabular}{|c|c|c|c|c|}
\hline & تشكيلا نرسيل أشياء مثلث مستطيلة & & & \\
\hline 7 & 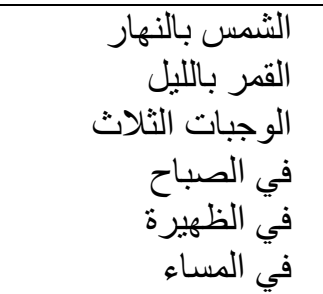 & صنارًا، ظليل & مفردات الزمن &.$\varepsilon$ \\
\hline \multicolumn{2}{|r|}{$r r$} & 10 & \multicolumn{2}{|l|}{ الاجمالي } \\
\hline
\end{tabular}

استراتيجيات تعليم وتعلم أنشطة البرنامج: تم استخدام مجموعة متتوعة من الإستراتيجيات مثل (العصف الذهني، الحوار والهناقنـة، العمل الفردي، المسابقات، اللعب الإيهامي ...).

\section{الأدوات والوسائل المستخدمة في البرنامج: الإبهي:}

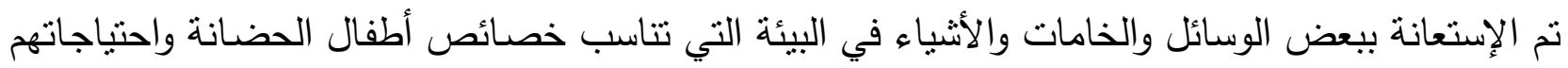

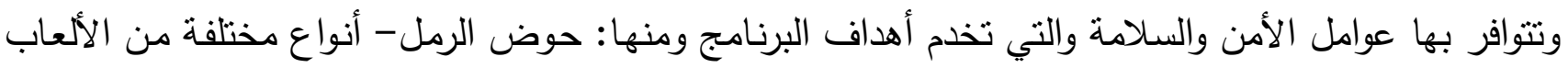

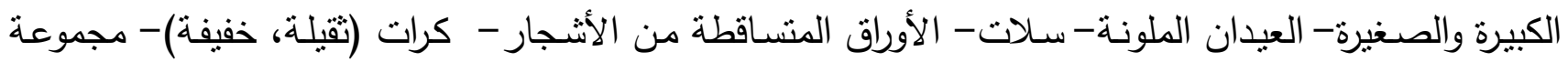

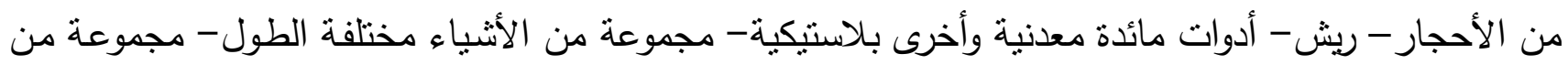

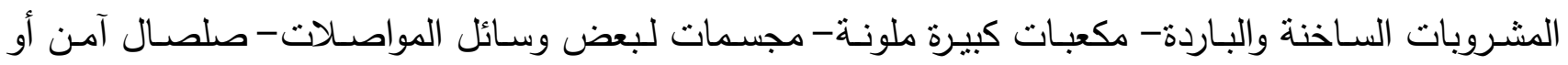

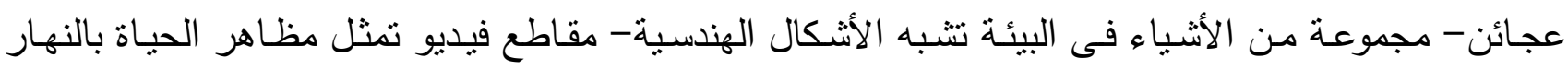
وبالليل- مجموعة من بعض الأطعمة المختلفة- مجموعة من الصور التي تمثل أحداث الروتين اليومي للطفل-

$$
\text { \# }
$$

تتوعت وسائل التقويم المستخدمة للحكم على مدى نجاح البرنامج على النحو التالي: - التقويم القبلي: نم من خلال تطبيق اختبار اللغة الرياضياتية المصور للتعرف على خلفية الطفل المعرفية والوقوف على مستوى اللغة الرياضياتية لليه. - التقويم المرحلي: وهو تقويم مصاحب من بداية البرنامج وحتى نهايته ونم هذا النوع من الثقويم من خلال: ملاحظة سلوك الأطفال اليومي أثناء تأدية الأنشطة بهدف التعرف على مدى تجاوب لهاب الأطفال للخبرات المقدمة لهم والتعرف على جوانب القوة والضعف ومحاولة علاجها.

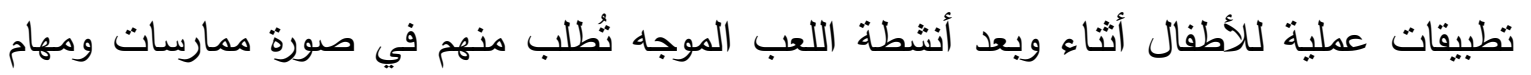
يقومون بأدائها بصورة فردية وجماعية. 
- التقويم البعدي: تم من خلال إعادة تطبيق اختبار اللغة الرياضياتية المصور والذي تم تطبيقه قبل تتفيذ

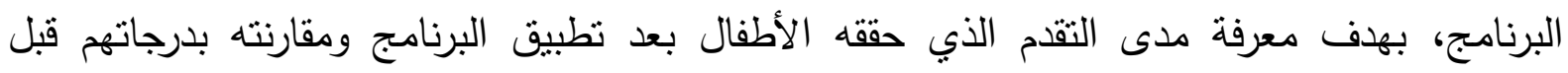
التطبيق.

\section{عرض البرنامج على السادة المحكمين:}

تم عرض البرنامج على مجموعة من السادة المحكمين من ذوي الخبرة والتخصص في مجال التربية ورياض

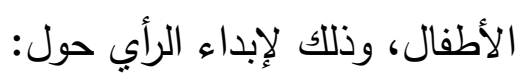
- مدى ارتباط أهداف البرنامج السلوكية بالهدف العام.

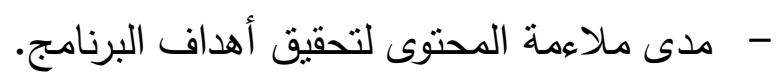

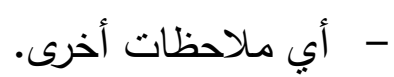
وقد أبدى السادة المحكمون بعض الملاحظات منها: - تعديل صياغة بعض الأهداف السلوكية. - - إضافة بعض العناصر لمحتوى الأنشطة.

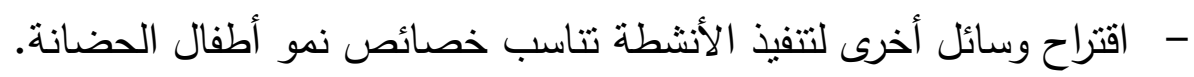

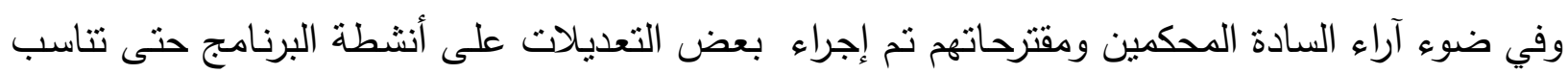

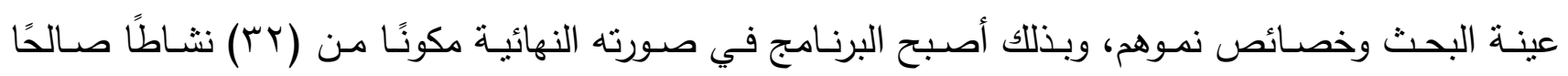
للنطبيق على عينة البحث المستهوفة.

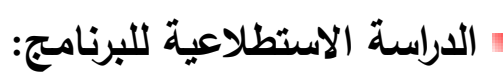

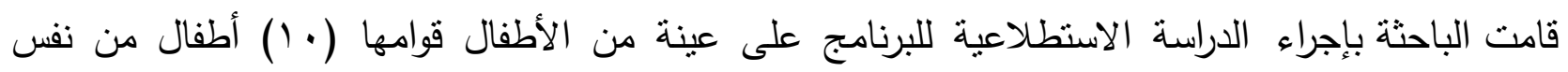

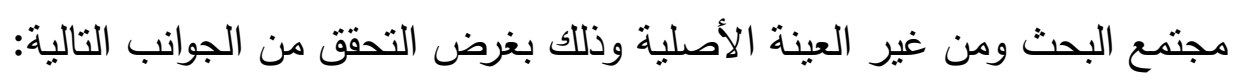
- - معرفة مدى ملائمة البرنامج للأطفال.

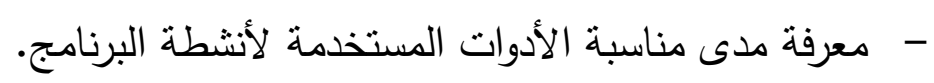

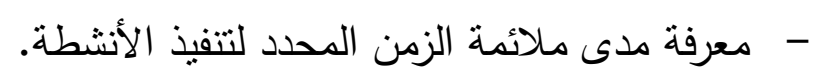
- تحديد الصعوبات التي قد نواجه الباحثة.

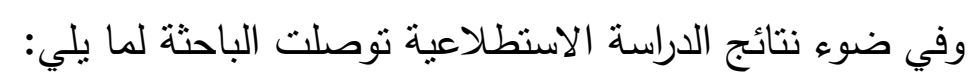

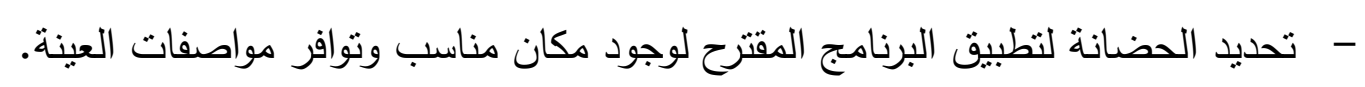
- - مناسبة الأدوات والوسائل والأنشطة لتحقيق الأهداف المحددة. - - تحديد الفترة الزمنية لنطبيق البرنامج. 
الخطة الزمنية لتنفيذ البرنامج:

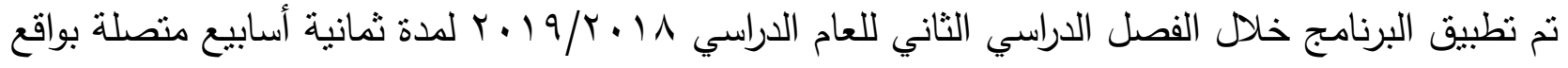

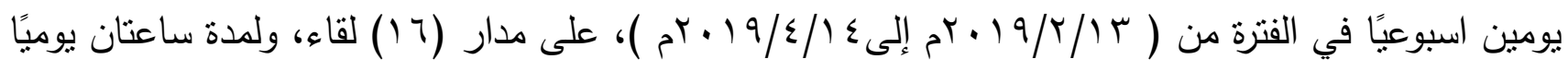
تقريبًا، بمعدل نشاطين في اليوم الواحد، وبذللك قد تم الإجابة على السؤال الثاني.

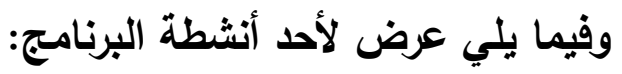

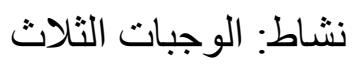

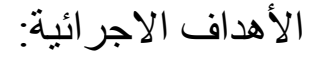

$$
\text { - - ميدرك مفردات الزمن (صباحًا، ظهرًا، مساءًا). }
$$

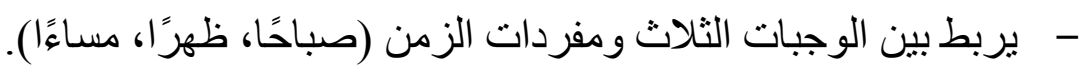
- - - يشارك في القيام ببعض المهام المحبية إليه.

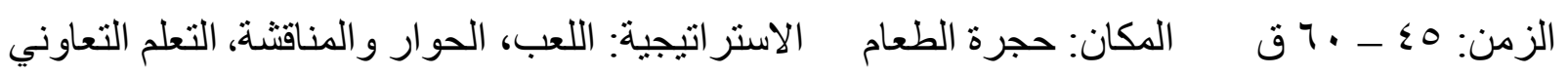
المو ادو الأدوات: مجمو عة من الأطعمة المختلفة، بطاقة تقويمية.

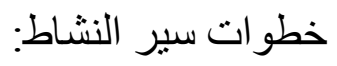
تهيئة: تبدأ المعلمة بتهيئة الأطفال بأن تسألهم: مين بيساعد ماما في تجهيز الأكل؟ وبتعمل إيه؟

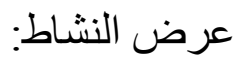
- تعرض المعلمة على الأطفال مجمو عة من الأطعمة المختلفة.

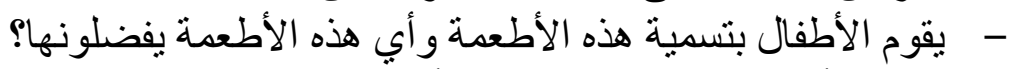

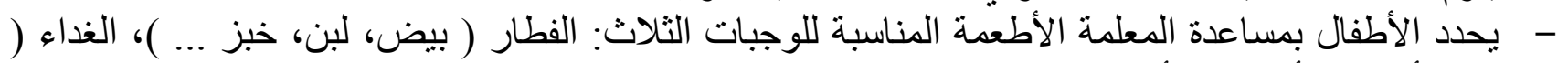

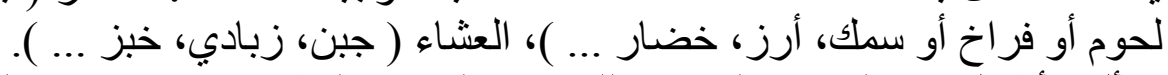
- تسأل الأطفال عن التوقيت المناسب للوجبات الثناث: الفطار يكون صباحًا، الغداء يكون ظهرًا، العشاء يكون - - تعرض على الأطفال بطاقات مصورة تمثل السمات المميزة لوقت الصباح مثل (شروق الثمس)، وقت الظهر

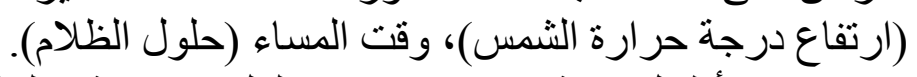

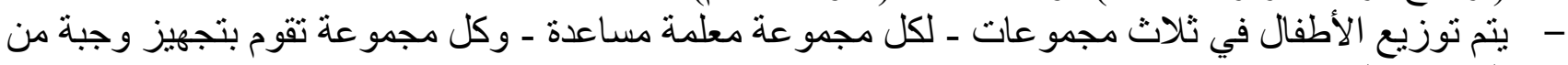

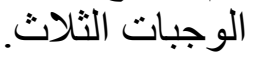

التقويم: يوصل الطفل بين صورة كل وجبة من الوجبات الثناث (الفطار، الغذاء، العشاء) و الصورة الدالةة على

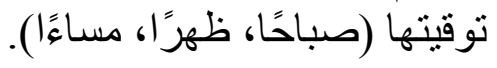




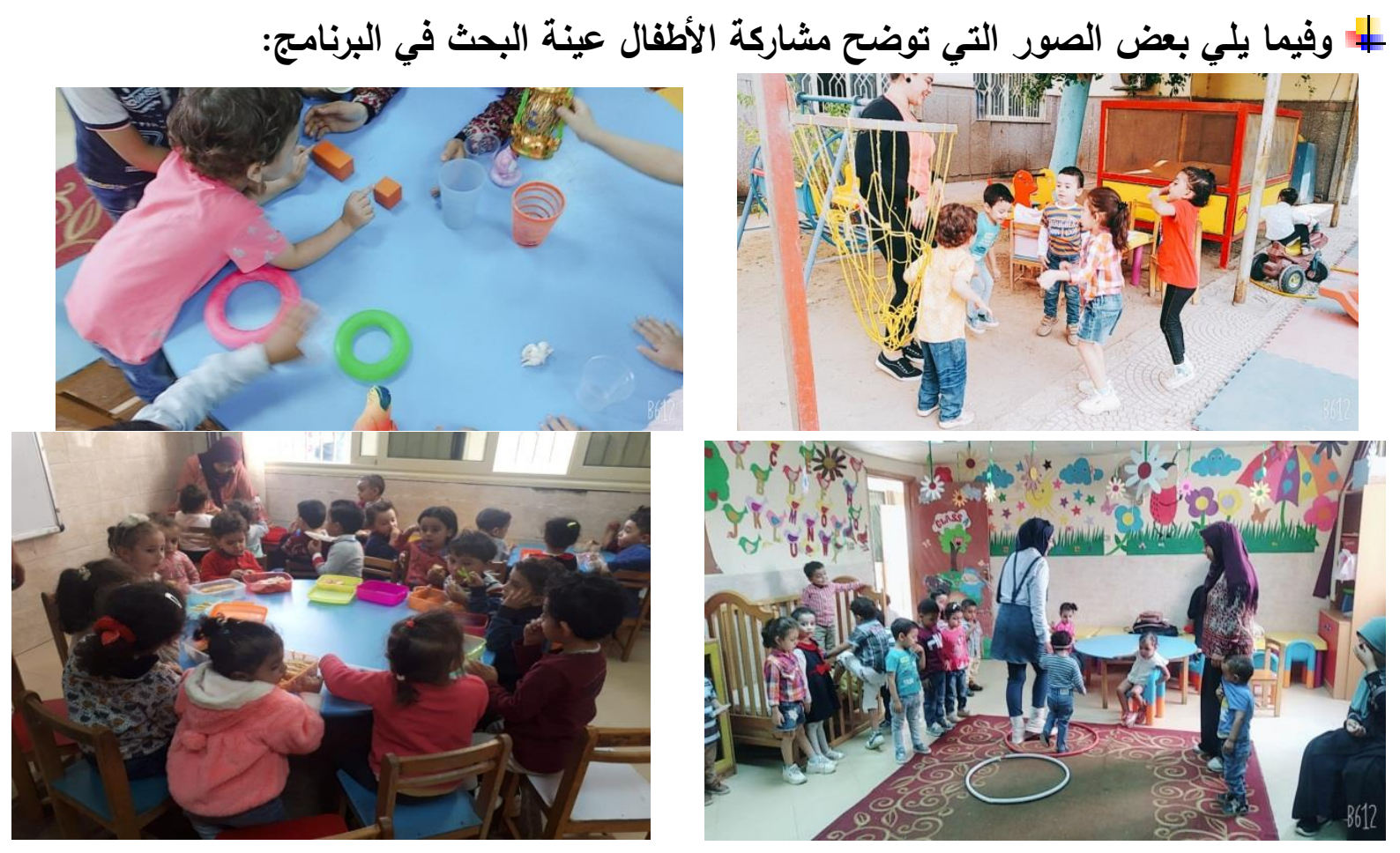

r. اختبار اللغة الرياضياتية المصور لطفل الحضانة: ملحق رقم (ץ) |

الكثف عن مستوى مفردات اللغة الرياضياتية ( المقارنة، الموقع المكاني، الأثكال الهندية، الزمن ) لدى طفل الحضانة.

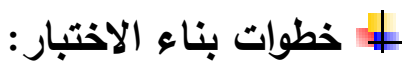
نم إعداد الاختبار طبقاً للخطوات التالية: - الاطلاع على بعض المراجع العربية في القياس النفسي والتربوي للتعرف على كيفية بناء الإختبارات وإعدادها وخصائص الاختبار الجيد. - الاطلاع على بعض المراجع والدراسات المرتبطة للإستفادة منها في طريقة تصميم الاختبار ومنها: صالح،

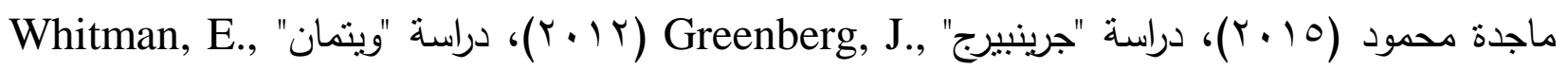

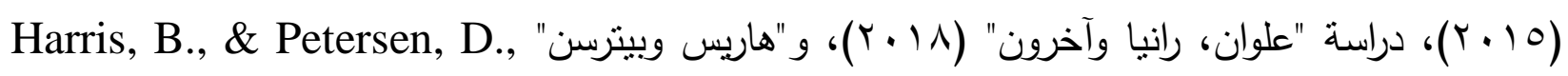
$\cdot(r \cdot 19)$ - تكون الاختبار في صورته الأولية من مجموعة أسئلة مصورة بلغ عددها (ع؟) سؤال تتدرج تحت أربع فئات من مفردات اللغة الرياضياتية التي يمكن تطويرها لدى طفل الحضانة هي: ( المقارنة، الموقع المكاني، الأثنكال الهندسية، الزمن ). - تم عرض الاختبار فى صورته المبئية على مجموعة من الخبراء المتخصصين في رياض الأطفال وعلم

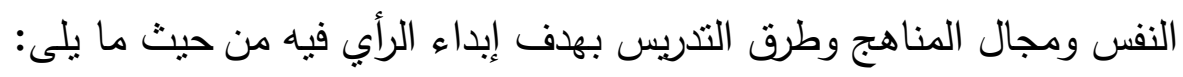


حذف أو إضافة أو تعديل أى سؤال أو صورة لا تتناسب مع الهدف أو سن الأطفال.

التأكد من تحقيق الاختبار للهيف المراد قياسه.

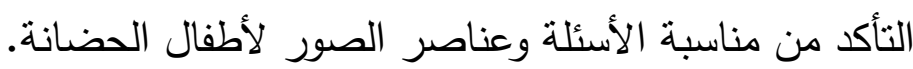
- وطرح السادة المحكمون بعض الملاحظات على الاختبار منها:

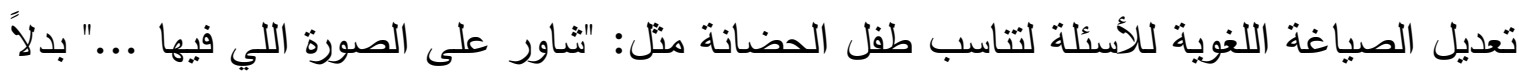
من "ضع دائرة حول الصورة اللي فيها ...". حذف بعض الأسئلة الخاصة ببعد "الزمن" نظرًا لصعوبتها وتداخلها والإكتفاء بسؤال واحد فقط لكل مفهوم (نهاراً، ليلاً، صباحاً، ظهراً، مساءًا). تغيير بعض الصور التي لا تتتاسب مع سن الأطفال. • استبدالة بعض عناصر الصور الغير مألوفة لطفل الحضانة. الاختبار فى صورته النهائية :

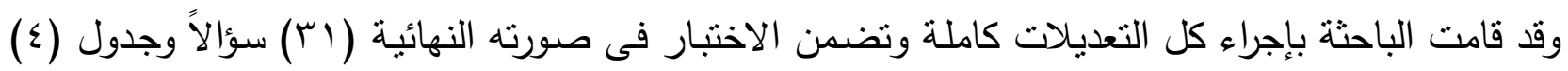
النالي يوضح الثكل النهائي للاختبار :

جدول (\&) ( ) الثكل النهائي لاختبار اللغة الرياضياتية المصور لطفل الحضانة والنسب المئوية لآراء السادة المحكمين

\begin{tabular}{|c|c|c|c|c|c|}
\hline المئوية & الأسئلة & السؤال & المفردات & الأبعاد & p \\
\hline \multirow[t]{5}{*}{$\% 1 \cdots$} & \multirow[t]{5}{*}{$1 \cdot$} & \multirow[t]{5}{*}{$1 \cdot-1$} & الحجم (كبير، صغير) & \multirow{5}{*}{$\begin{array}{c}\text { الدقارنة } \\
\text { Comparing }\end{array}$} & \multirow[t]{5}{*}{.1} \\
\hline & & & الكمية (كثير ، قليل) & & \\
\hline & & & الوزن (نقيل، خفيف) & & \\
\hline & & & الطول (طويل، قصبر) & & \\
\hline & & & الحر ارة (ساخن، بارد) & & \\
\hline \multirow[t]{4}{*}{$\% 90$} & \multirow[t]{4}{*}{$\wedge$} & \multirow[t]{4}{*}{$\left|\Lambda_{-}\right| 1$} & داخل، خارج & \multirow{4}{*}{$\begin{array}{r}\text { الموقع المكاني } \\
\text { Positional }\end{array}$} & \multirow[t]{4}{*}{ r } \\
\hline & & & فوق، تحت & & \\
\hline & & & أمام، خلف & & \\
\hline & & & يمين، يسار & & \\
\hline \multirow[t]{4}{*}{$\% 1 \cdots$} & \multirow[t]{4}{*}{$\Lambda$} & \multirow[t]{4}{*}{ r. 19} & دائرة & \multirow{4}{*}{ الأشكال الهندسية } & \multirow[t]{4}{*}{$r$} \\
\hline & & & هربع & & \\
\hline & & & مستطيل & & \\
\hline & & & مثلث & & \\
\hline \multirow[t]{2}{*}{$\% 9$. } & \multirow[t]{2}{*}{0} & \multirow[t]{2}{*}{ TI } & نهار ، ليل & \multirow[t]{2}{*}{ Time الزمن } & \multirow[t]{2}{*}{$\varepsilon$} \\
\hline & & & صباحًا، ظهرًا، مساءًا & & \\
\hline
\end{tabular}

يتضح من جدول (ع) السابق أن نسب اتفاق السادة المحكمين على أبعاد المقياس ترواحت بين ( 99\% -

ا. التقرب من الطفل ومحاولة إزالة عامل الرهبة لديه وتكوين علاقة إيجابية معه قبل تطبيق الاختبار. 
r. تقديم أسئلة الاختبار باللهجة العامية المألوفة وبصورة تتلاعم مع خصائص نمو طفل الحضانة. r. وضع كل سؤال في صفحة حتى لا يؤثز ذلك على أداء الأطفال وعدم تركيزهم. ع. بطبق الاختبار بطريقة فردية، مع ضرورة إعداد استمارة مستقلة لكل طقل يتم فيها تسجيل الإجابات في أماكنها المناسبة. 0. تعزيز استجابة الطفل للمحافظة على استمرار دافعيته في الإجابة على الاختبار . 7. يتم توجيه السؤال لفظيًا بصوت واضح وعلى الطفل أن يختار الإجابة الصحيحة من ثلاثة اختيارات مصورة إما بالذكر أو بالإشارة على الصورة المعبرة عن إجابته. تقدير درجات الاختبار :

لتقدير درجات الاختبار نت اتباع نظام إعطاء درجة واحدة أو صفر ، فيعطى الطفل درجة واحدة في حالة إجابته الصحيحة، والبدائل الأخرى تمثل إجابات خاطئة ويتم إعطائه صفر وبالتالي تكون درجة الاختبار الكلية ( ) (ب) درجة.

\section{التجرية الاستطلاعية للاختبار:}

تم تطبيق الاختبار على عينة استطلاعية بلغ عددها ( . . () طفلاً وطفلة من أطفال الحضانة من مجتمع البحث ومن غير العينة الأصلية وذلك بغرض التحقق من الجوانب التالية: - مدى مناسبة الاختبار للأطفال من حيث وضوح الصور وفهم الأسئلة، وقد وجدت الباحثة أن الاختبار مناسبًا لأطفال الحضانة. - - مساب زمن تطبيق الاختبار -

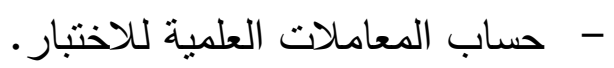
زمن تطبيق الاختبار: قامت الباحثة بحساب متوسط الأزمنة التي استغرقتها الأطفال في تطبيق الإختبار ، وقد ترواح بين (. (( 10

\section{المعاملات العلمية للاختبار:}

قامت الباحثة بإجراء معاملات الصدق والثبات ومعاملات السهولة والصعوبة والتمييز لأسئلة الاختبار وذلك على عينة قوامها ( . . 1) طفلًا من غير عينة البحث الأصلية. 


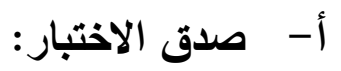 \\ معاملات صدق الاختبار:

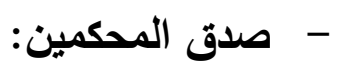

تم عرض الاختبار في صورته المبئية على مجموعـة من السـادة المحكمين المتخصصين في المجالات التربوية والنفسية؛ لتحديد صدق المحتوى للاختبار طبقًا للتعريف الإجرائي وأبعاده، وتم إجراء التعديلات المقترحة

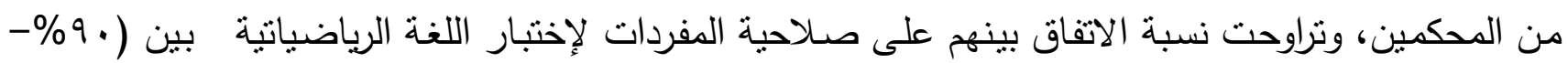

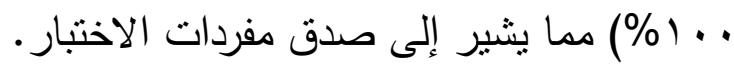

- - الصدق التمييزي: -

قامت الباحثة بحساب معاملات ارتباط المفردات مع جميع أبعاد الاختبار كمؤشر للصدق التمييزى للاختبار وجدول (0) يوضح ذللك:

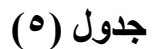

معاملات ارتباط المفردات مع أبعاد الاختبار كمؤشرات للصدق التمييزى إنيات

\begin{tabular}{|c|c|c|c|c|}
\hline \multicolumn{4}{|c|}{ معاملات الارتباط } & \multirow[b]{2}{*}{ رقم المفردة } \\
\hline الزمن & الاثكال الهندسية & الموقع المكانى & المقارنة & \\
\hline-.013 & $.219^{*}$ & .012 & $.531^{* *}$ & 1 \\
\hline .058 & $.225^{*}$ & .048 & $.431^{* *}$ & T \\
\hline .021 & -.075 & .194 & $.455^{* *}$ & $r$ \\
\hline $199^{*}$ & -.033 & $.200^{*}$ & $.335^{* *}$ & $\varepsilon$ \\
\hline-.078 & .135 & .151 & $.354^{* *}$ & 0 \\
\hline-.067 & .066 & .086 & $.312^{* *}$ & 7 \\
\hline-.050 & .053 & .123 & $.319^{* * *}$ & $\mathrm{~V}$ \\
\hline .113 & .077 & .102 & $.253^{*}$ & $\Lambda$ \\
\hline-.009 & -.060 & -.033 & $.210^{*}$ & 9 \\
\hline-.017 & -.003 & -.015 & $.247^{*}$ & 1. \\
\hline-.167 & .022 & $.346^{* *}$ & .164 & 11 \\
\hline .004 & .089 & $.412^{* * *}$ & .087 & Tr \\
\hline-.132 & -.040 & $.337^{* * *}$ & .109 & 14 \\
\hline-.035 & -.034 & $.388^{* * *}$ & .058 & $1 \varepsilon$ \\
\hline-.017 & .051 & $.290^{* * *}$ & .189 & 10 \\
\hline .145 & .135 & $.365^{* *}$ & .077 & 17 \\
\hline .119 & -.083 & $.346^{* *}$ & .073 & IV \\
\hline $.250^{*}$ & .010 & $.464^{* * *}$ & .006 & 11 \\
\hline-.151 & $.348^{* *}$ & .192 & .147 & 19 \\
\hline$-.256^{*}$ & $.326^{* *}$ & -.053 & -.179 & $r$. \\
\hline-.135 & $.446^{* *}$ & $.221^{*}$ & $298^{* *}$ & r) \\
\hline-.082 & $.324^{* *}$ & -.080 & -.055 & $\overline{Y Y}$ \\
\hline .099 & $.366^{* *}$ & .172 & $.229^{*}$ & $\overline{T r}$ \\
\hline
\end{tabular}




\begin{tabular}{|c|c|c|c|c|}
\hline $.292^{* *}$ & $.295^{* *}$ & -.124 & -.044 & $T \xi$ \\
\hline $.284^{* *}$ & $.530^{* *}$ & .179 & .142 & To \\
\hline .135 & $.561^{* *}$ & -.165 & -.038 & YT \\
\hline $.369^{* * *}$ & $.336^{* * *}$ & -.070 & .129 & TV \\
\hline $.358^{* * *}$ & $.286^{* * *}$ & -.081 & $.207^{*}$ & TA \\
\hline $355^{* *}$ & .009 & .027 & -.069 & rq \\
\hline $.698^{* *}$ & -.033 & .130 & -.030 & $r$. \\
\hline $.763^{* *}$ & .068 & .155 & -.015 & $T_{1}$ \\
\hline
\end{tabular}

يلاحظ من نتائج جدول (0) أن معاملات ارتباط العبارات بأبعادها أعلى لو قورنت بارتباطها مع الأبعاد الأخرى، على سبيل المثال مفردات رقم (1-r-r-צ-0بينما كانت ضعيفة جدًا بالأبعاد الأخرى، وهكذا بالنسبة لباقى المفردات للأبعاد ( الثانى والثالث والرابع ) كما هو مبين بالجدول، وهذا يؤكد على تمتع الاختبار بصدق تمبيزى مرتفع.

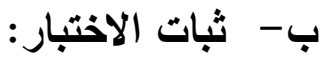

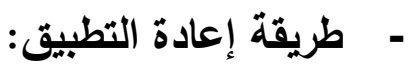
وقد نت حساب معامل الارتباط بين التطبيق الاول والثانى على عينة مكونة من (•r) طفلاً من غير عينة البحث الأصلية وينطبق عليها نفس شروط العينة الأصلية، كما يتضح في جدول (ج) التالي:

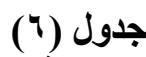
معامل الثبات بطريقة إعادة التطبيق

\begin{tabular}{|c|c|}
\hline معامل الارتباط & الأبعاد \\
\hline$* *, . \vee 10$ & المقارنة \\
\hline **..人T & الموقع المكاني \\
\hline **..VTr & الأشثكال الهندسية \\
\hline 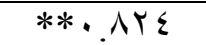 & الزمن \\
\hline
\end{tabular}
** دالةة عند مستوى I ... يتضح من جدول (T) السابق ارتفاع معاملات الارتباط مما يدل على ثبات الاختبار .

\section{ج- تحليل مفردات الاختبار ( لحساب معاملات السهولة والصعوية والتمييز لأسئلة الاختبار ):} قامت الباحثة باجراء دراسة استطلاعية للتعرف على مناسبة الاختبار للتطبيق على مجتمع البحث وذلك من خـله تطبيقه على عينـة عشوائية قوامها ( . . ( ) طفل من مجتمـع البحث ومـن غبر العينـة الأصلية لحسـاب معاملات السهولة والصعوبة والتمبيز لأسئلة الاختبار ، وتراوحت معاملات السهولة والصعوبة لأسئلة الاختبار ما

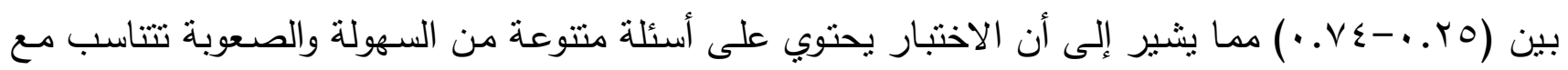

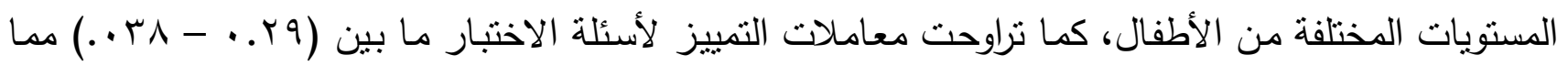


يوضـح أن الاختبار ذو قوة تمييزية مقبولة، وبهذا يكون الاختبار صـالحًا للتطبيق كأداة معرفية تتاسب أطفال

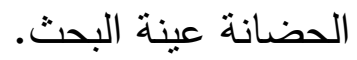
\$ وفيما يلي عرض لبعض أسئلة الاختبار المصور: مفردات المقارنة: فين الحيوان الثقيل ؟ اليفي
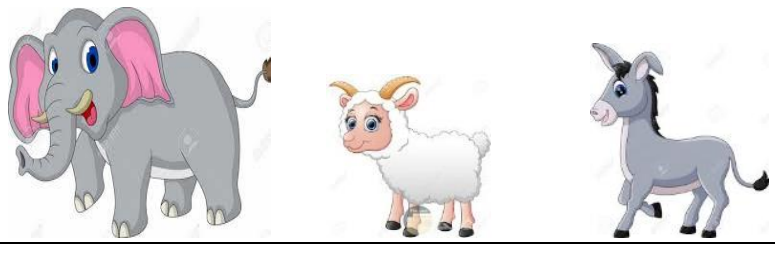

مفردات الموقع المكاني: شاور على الصورة اللي فيها العصفور داخل الققص ؟
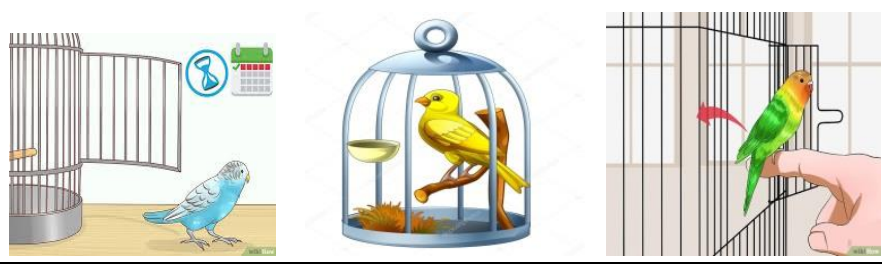

مفردات الأشكال الهندية: شاور على الثئ اللي شبه شكل المثلث ؟
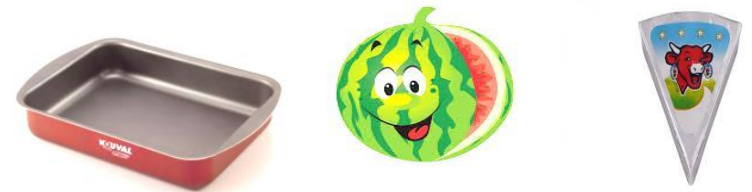

مفردات الزمن: شاور على أنشطة الصورة اللي بنعملها في المساء؟
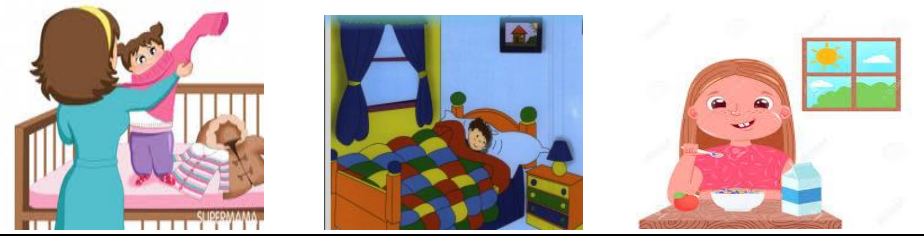

\section{إجراعات البحث الميدانية:}

اتبعت الباحثة عددًا من الإجراءات تشمل ما يلي:

الاطلاع على الأدبيات والدراسات السابقة ذات الصلة بموضوع البحث.

إعداد قائمة مفردات اللغة الرياضياتية لطفل الحضانة.

إعداد برنامج أنشطة اللعب الموجه لتطوير اللغة الرياضياتية لدى طفل الحضانة.

القيام بالدراسة الاستطلاعية للبرنامج.

بناء اختبار اللغة الرياضياتية المصور لطفل الحضانة. 
التحقق من صدق وثبات اختبار اللغة الرياضياتية بالأساليب الإحصائية المناسبة.

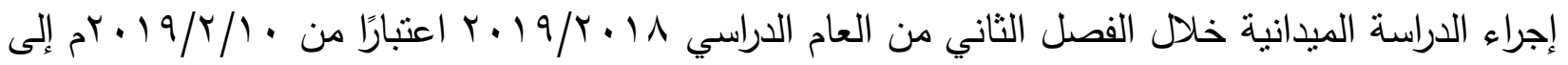

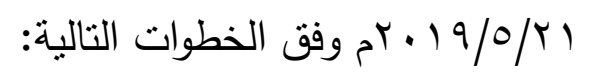

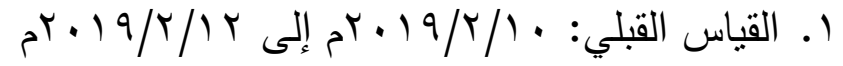

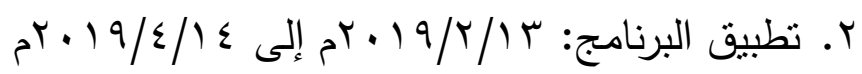

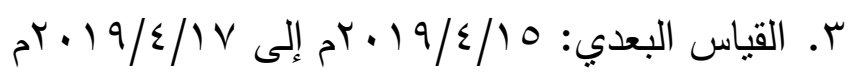

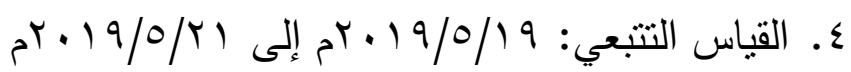

حساب النتائج بالأساليب الإحصائية المناسبة.

تفسير النتائج ومناقشتها.

تقديم التوصيات والمقترحات.

\section{نتائج البحث: تفسيرها ومناقثتثها: الفرض الأول:}

توجد فروق دالة إحصائيًا بين متوسطات درجات أطفال المجموعة التجريبية في القياسين القبلي والبعدي على اختبار اللغة الرياضياتية المصور لطقل الحضانة في اتجاه القياس البعدي.

وللتحقـق مـن صـحة هـذا الفـرض تـم اسـتخدام اختبـار "T-Test" للعينـات المرتبطـة Paired-Samples ويوضح جدول (V) التالي نتائج ذلك:

جدول (v)

نتائج اختبار "T-Test" لدلالة الفروق بين متوسطات درجات المجموعة التجريبية في القياسين القبلي والبعدي على اختبار اللغة الرياضياتية المصور

$r \mathrm{r}=\dot{0}$

\begin{tabular}{|c|c|c|c|c|c|c|c|c|c|}
\hline \multirow{2}{*}{ التأثير } & \multirow[b]{2}{*}{ ايتاب } & \multirow[b]{2}{*}{ اتجاه الدلالة } & \multicolumn{2}{|c|}{$\begin{array}{c}\text { قيمة(ت) ودلالتها } \\
\text { Df(31) }\end{array}$} & \multicolumn{2}{|c|}{ البعدى } & \multicolumn{2}{|c|}{ القبلى } & \multirow[t]{2}{*}{ الأبعاد } \\
\hline & & & 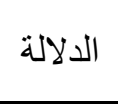 & القيمة & الالنحر اف & المتوسط & الالحيارى اف & المتوسط & \\
\hline كبير & 0.99 & القياس البعدي & 0.001 & 74.27 & .70 & $9 . \mu$ & .0 & $\varepsilon .0$ & المقارنة \\
\hline كبير & 0.97 & القياس البعدي & 0.001 & 36.19 & $\because V V$ & 7. $\mathrm{V}$ & .0 & r. & الموقع المكانى \\
\hline كبير & 0.98 & القياس البعدي & 0.001 & 39.19 & $\cdot \leqslant 9$ & $\vee .7$ & $\because \leqslant 0$ & $\varepsilon . r$ & الأشكال الهندسية \\
\hline كبير & 0.96 & القياس البعدي & 0.001 & 28.76 & $\cdot \varepsilon r$ & $\varepsilon . r$ & 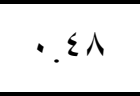 & 1.7 & الزمن \\
\hline
\end{tabular}

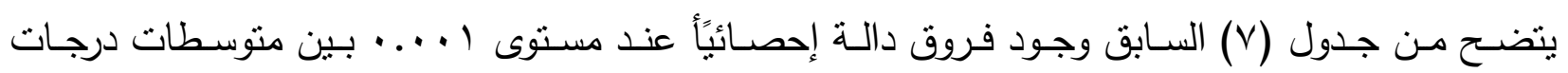
المجموعـة التجربيـة في القياسـين القبلي والبعدي على اختبـار اللغـة الرباضـياتية المصسور ( المقارنـة، الموقـع المكاني، الأشكال الهندسية، الزمن ) لصالح القياس البعدى. 


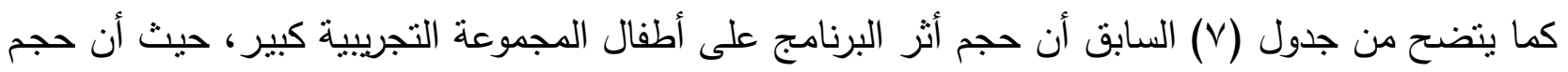

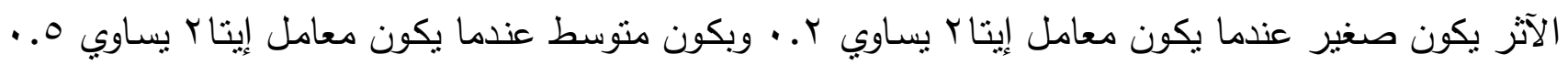
ويكون كبير عندما يكون معامل إيتا ب بساوي ^^...

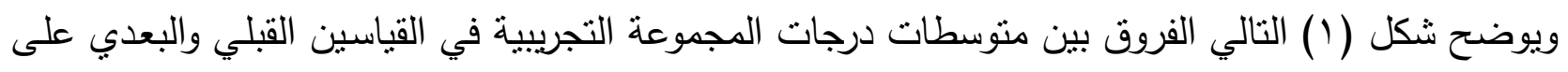
اختبار اللغة الرياضياتية المصور .

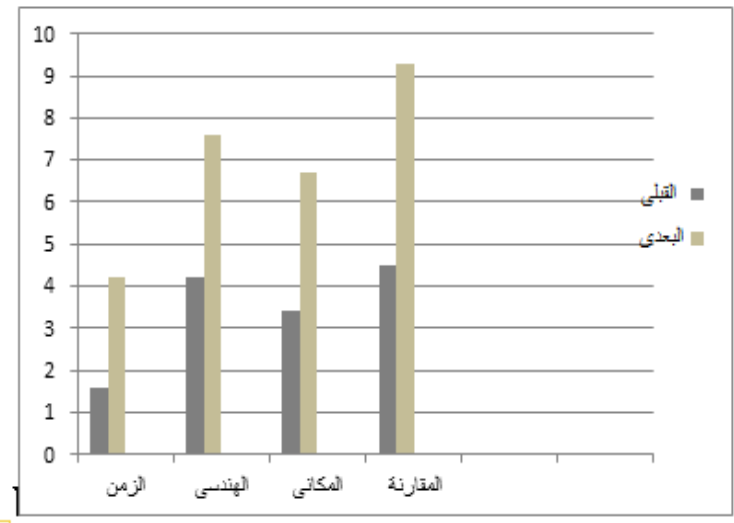

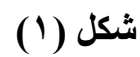

الفروق بين متوسطات درجات المجموعة التجريبية في القياسين القبلي والبعدي على اختبار اللغة الرياضياتية المصور

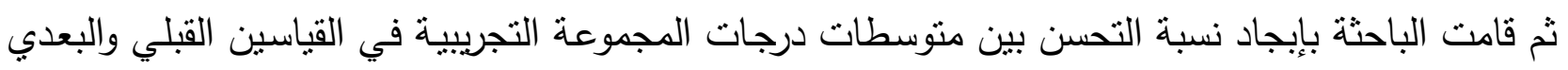

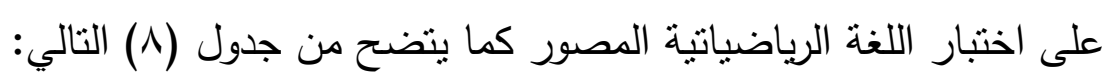

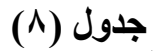

نسبة التحسن بين متوسطات درجات المجموعة التجريبية في القياسين القبلي والبعدي على اختبار اللغة الرياضياتية المصور

\begin{tabular}{|c|c|c|c|c|c|c|c|}
\hline \multirow[t]{2}{*}{ نسبة التحسن } & \multicolumn{2}{|c|}{$\begin{array}{c}\text { قيمة (ت) ودلالتها } \\
\text { Df(31) }\end{array}$} & \multicolumn{2}{|c|}{ البعدى(r (r) } & \multicolumn{2}{|c|}{ القبلى (r ץ F) } & \multirow[t]{2}{*}{ المتغيرات } \\
\hline & الالالة & القيمة & الالمعراف & المتوسط & الالاتحراف & المتوسط & \\
\hline$\% 51.6$ & 0.001 & 74.27 & .70 & $9 . r$ & .0 & $\varepsilon .0$ & المقارنة \\
\hline$\% 49.25$ & 0.001 & 36.19 &. $\mathrm{VV}$ & $7 . \mathrm{V}$ & $\because 0$ & r.s & الموقع المكانى \\
\hline$\% 44.73$ & 0.001 & 39.19 &. .89 & $v .7$ &..$\leqslant 0$ & $\varepsilon . Y$ & الأشكال الهندسية \\
\hline$\% 61.90$ & 0.001 & 28.76 &..$\leqslant Y$ & $\varepsilon . Y$ &..$\leqslant \Lambda$ & 1.7 & الزمن \\
\hline
\end{tabular}

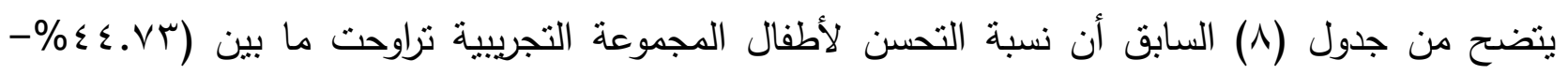

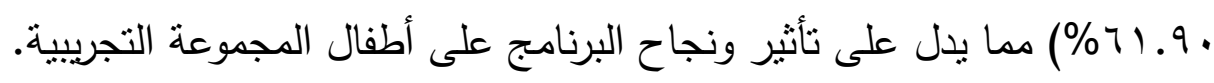
تفسير ومناقشة نتائج الفرض الأول:

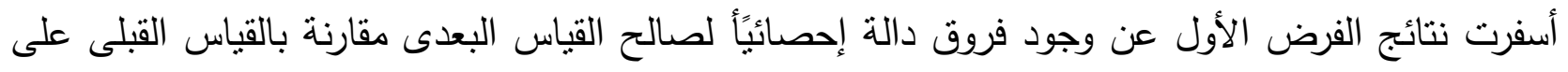

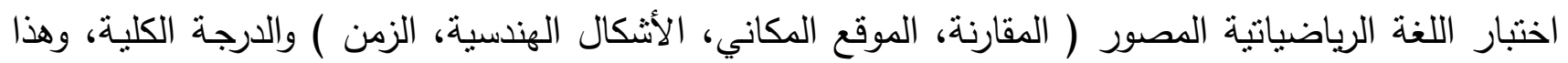


يثنير إلى وجود أثز موجب ودالة لتأثير البرنامج القائم على أنشطة اللعب الموجه في تطوير مفردات اللغة الرياضياتية لدى أطفال الحضانة (عينة البحث)، وتُرجع الباحثة هذه النتيجة إلى طبيعة البرنامج الذي تميز بـ: - - التخطيط الجيد لخبرات وأنشطة البرنامـج:

فقد تم تخطيط خبرات وأنشطة اللعب الموجه المناسبة لأطفال الحضانة، وتحديد الأهداف والتظيم المكاني، والخامـات الأساسـية المطلوبـة، والأدوات المكملـة والوقت الــي سـوف يحتاجـه الأطفـال بهـدف تطـوير اللغـة

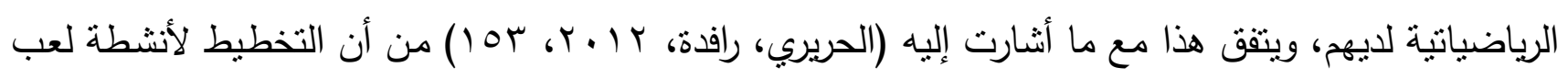
الأطفال من حيث تخطيط الأهداف والأنشظة التي على أساسها يتحدد بماذا وكيف ومتى يلعب الأطفال وتحديد الأدوات والوسائل التي على أساسها يتم تتظيم البيئة والمواد والألعاب التي تقدم للأطفال لتحقيق الأهداف المرجوة، وتحديد المدة الزمنيـة للعب، وتحديد المكان الذي يستوعب جميع الأطفال للإثتراك في اللعب مما يساعد في تفاعلهم مع بعضهم.

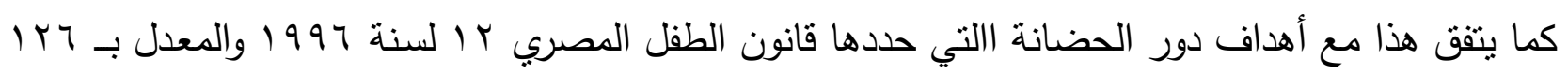
لسنة ^ . . ب فيما يخص بتلبية حاجة الأطفال للترويح ومزاولة الألعاب والأنشطة الترفيهية واعتبار اللعب مبداً أساسـياً مـن مبـادئ العمـل في دور الحضـانة، وكذلك مـع معـايير الجـودة لـور الحضـانة التي حددتها (وزارة التأمينات والثئون الاجتماعية (1 (1 ـ الخاصة بمجال الخبرات التربوية المناسبة لطفل الحضانة.

\section{- بيئة مشوقة وملائمة:}

فقد تم تزويد بيئة الطفل بأثنياء وخامات وألعاب وإمكانات اللعب المتاحة ذات نماذج نركيبية بنائية مثل المكعبات والرمال، وألعابًا مثل وسائل المواصلات أو الدمي بأحجام وأطوال وأعداد مختلفة وصفات مميزة، فالأطفال الصغار عادة ما يحتاجون للعب بأدوات حقيقية أو نماذج مجسمة لها لتدور حولها أحاديثهم باستخدام

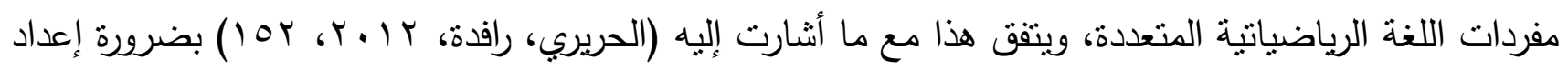

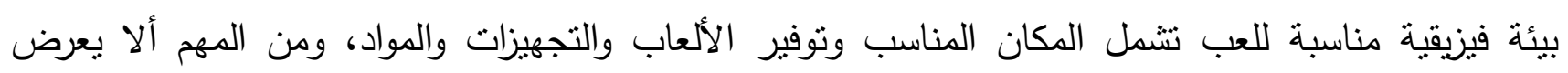
المربي العديد من مواد اللعب مرة واحدة حتى لا يسبب الحيرة والارتباك للأطفال الصغار . لصاب.

وتتفق هذه النتيجة أيضًا مـع مـا أوصت بـه دراسـة علوان، رانيا وآخرون (1 ( • r) بالحرص على إعداد بيئة

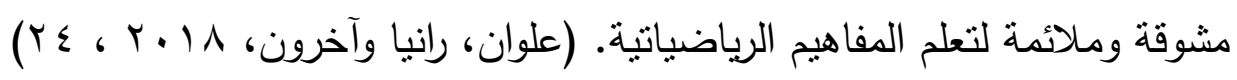
- جودة تصميم حديقة الحضانة (بيئةَ اللعبِ الخارجي): فقد توافرت الأدوات الملائمة في حديقة الحضانة كي تستخدم من قبل الأطفال أثناء فترة اللعب الخارجي، حتى تتسنى لهم الاستفادة منها خلال اللعب مما جعل هذا اللعبَ أكثرَ حيوية ونشاطاً، فبيئةَ اللعب الخارجي شجعت 
الأطفالَ كي يستطلعوا إمكانية استخدام أوراق الأثجار والحصى لتدور حولها أحاديثهم المتضمنة مفردات اللغة

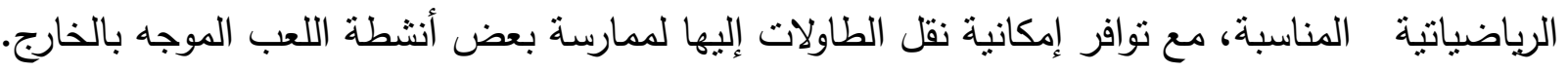

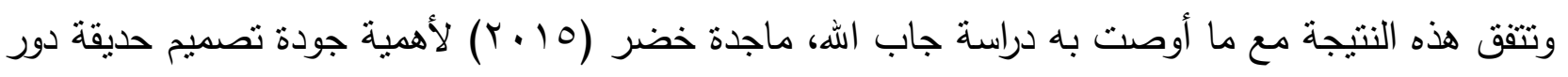

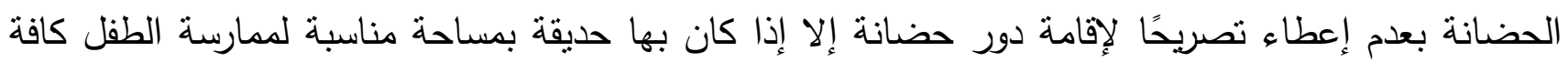

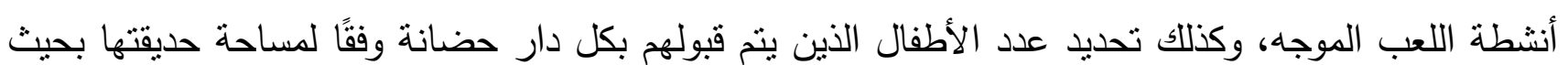

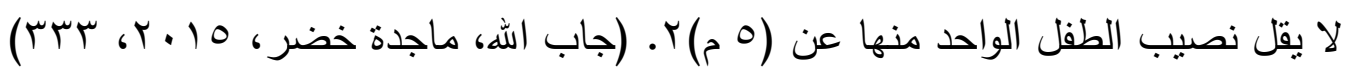
- توفير السلامة والأمان للأدوات والوسائل والألعاب:

توفير السلامة والأمان للأدوات والوسائل والألعاب بالتأكيد كان هو الاهتمام الأول لمراعاة مستوى عمر

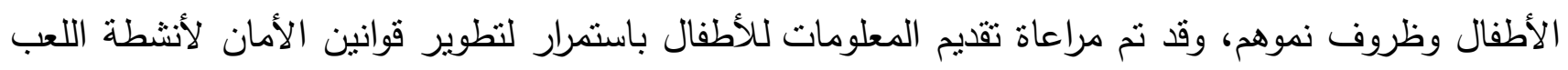

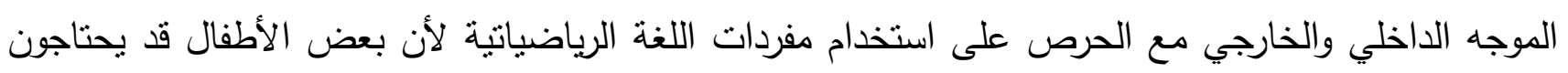
إلى تذكير دائم بهذه القوانين والتعليمات.

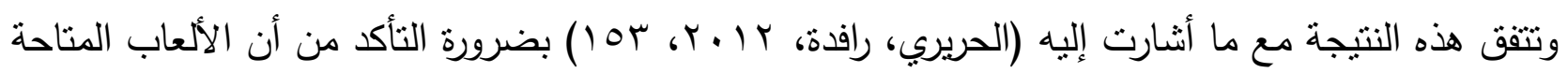

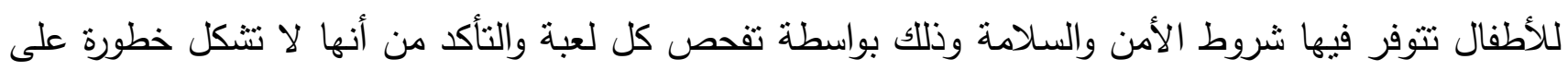
الأطفال كأن تكون صدئة أو ذات جواف حادة أو مكسورة أو ملوثة.

\section{- - استراتيجيات تعليم وتعلم تعتمد على إيجابية المتعلمين:}

تم إثراء أنشطة اللعب الموجه لدى الأطفال من خلال مناقتتهم فيما يلعبون وتوجيه أسئلة مفتوحة تساعدهم على الاستمرار في اللعب والتركيز فيه وتطوير مفردات اللغة الرياضياتية لديهم، فيجب على لئى المعلمة إثراك

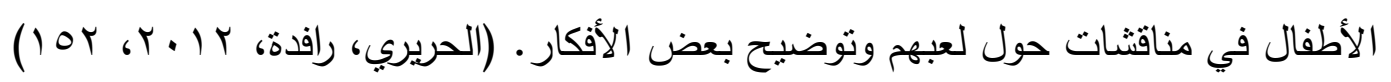

وتتفق هذه النتيجة مع ما أوصت به دراسة علوان، رانيا وآخرون (1) ب ب بتشجيع المعلمات بمرحلة الطقولة

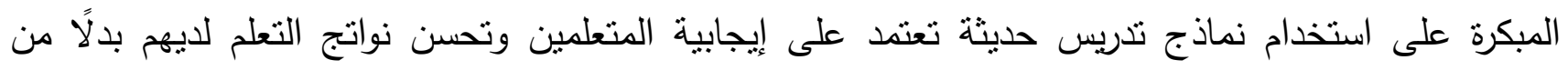

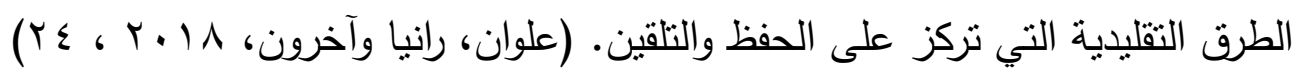

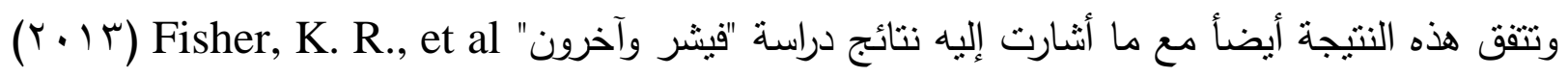
إلى أن تقنيات أنشطة اللعب الموجه تزيد من المشاركة والاستكثاف المباشر ، حيث ييني الأطفال المعرفة بنشاط عندما يستكثفون بيئتهم وينقاعلوا معها.

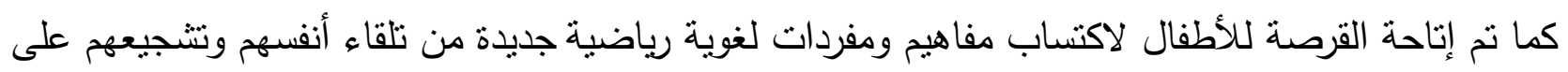
الاعتماد على النفس، فمن أساسيات البرامج التربوية والتعليمية في الحضانة التي حددتها (وزارة التتمية 


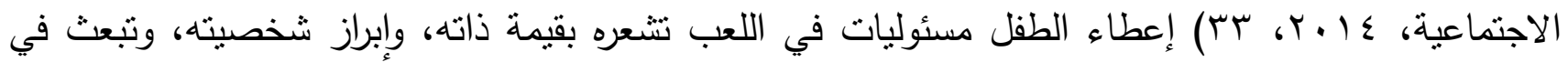
نفسه التقة، وتجعله يفهم قدراته.

حيث تتيح استخدام أنشطة اللعب فرصًا لتطوير مفردات اللغة الرياضياتية بطريقة ممتعة وترفيهية ومحفزة

للأطفال. (Riccomini, P. J., et al, 2015, 240-246)

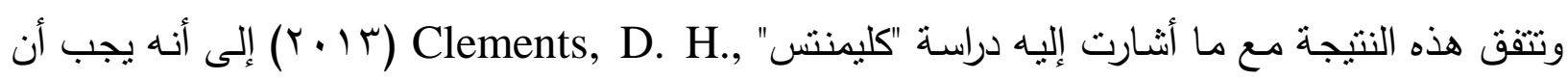
يتعرض الأطفال الصغار لخبرة الرياضيات من خلال مناهج قائمة على الممارسات التعليمية الفعالة.

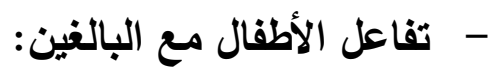
تم توفير فرص لتفاعل الأطفال مع البالغين (الباحثة والمعلمات الأخريات) أثناء أنشطة اللعب الموجه أوجدت

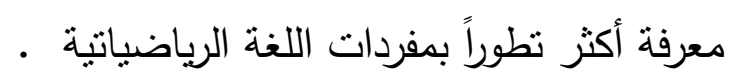

فمن فوائد اللعب الموجه أنه يمكن المعلمين من تعزيز استكثاف الأطفال وتعلمهح من خلال التعليق على

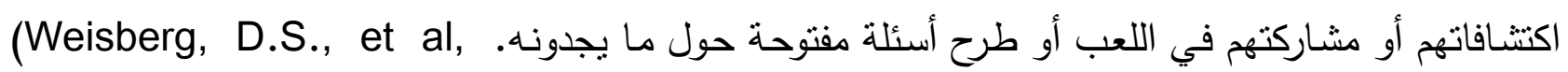
2013, 105-107)

وتتقق هذه النتيجة مع أساسيات البرامج التربوية والتعليمية في الحضانة التي حددتها (وزارة التتمية الاجتماعية،

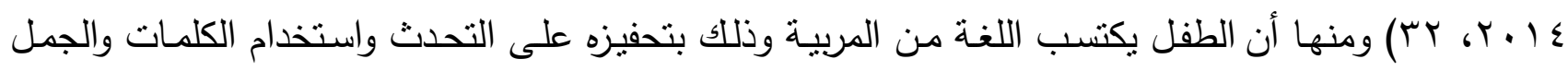

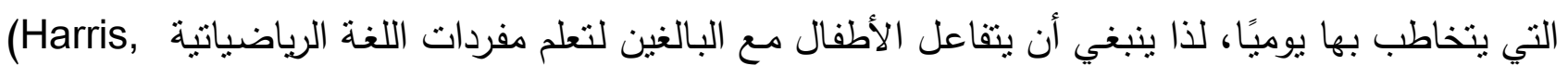

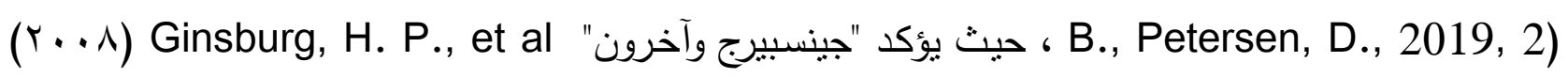
على أن اللغة الرياضياتية للمعلمين ترتبط ارتباطًا وثيقًا بنمو المعرفة الرياضياتية للأطفال.

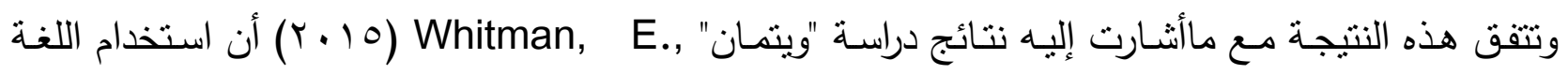

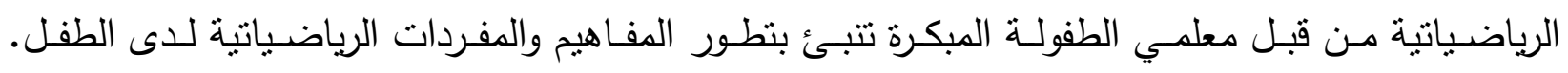
(Ginsburg, H. P., et al, 2008, 5)

\section{- تنوع الألعاب التي تم الاعتماد عليها في البرنامج:}

تم الاعتماد على مجموعة من الألعاب المتتوعة مثل الدمى، الألعاب الحركية، الألعاب التمثيلية، ألعاب الغناء

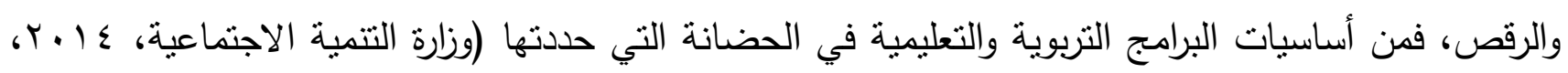
r r أن يتعلم الطفل بشكل غير مباشر بعض الخبرات المعرفية في ممارسته للأنشطة الحركية والاجتماعية

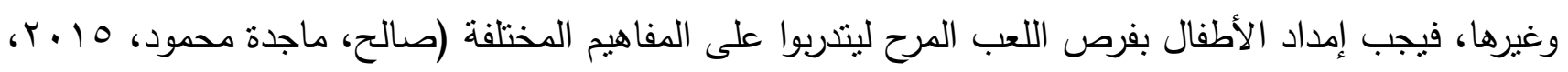




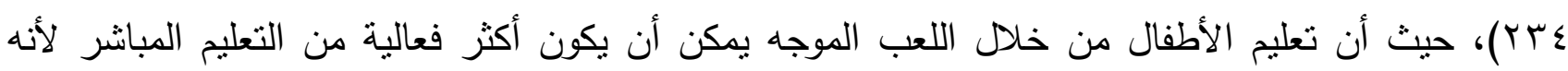

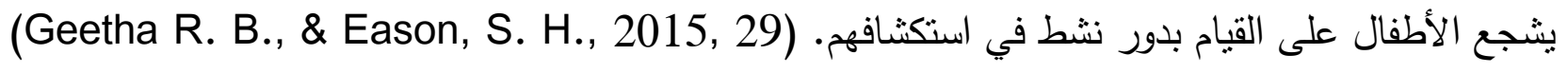
وتتقق هذه النتيجة مع ما قدمه "جيثا وإِيسون" Geetha R. B., \& Eason, S. H., (10 م من اقتراحات للمعلمين لإثراء قاعات النشاط بالمزيد من أنشطة الرياضيات المرحة، منها تشجيع المعلمين على تحديد الأنشطة

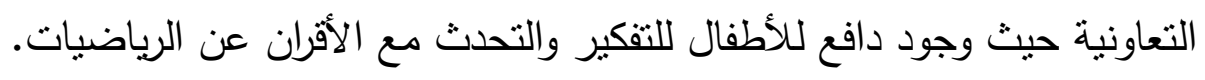

وتتفق هذه النتيجة أيضأ مع ما طرحه "ريكوميني وآخرون" Riccomini, P. J., et al (10 ب) من تقنيات

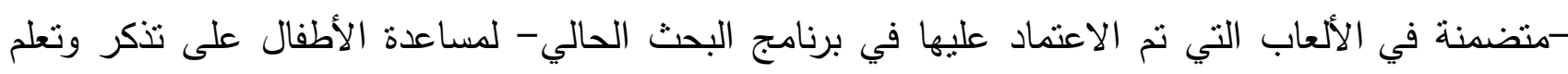

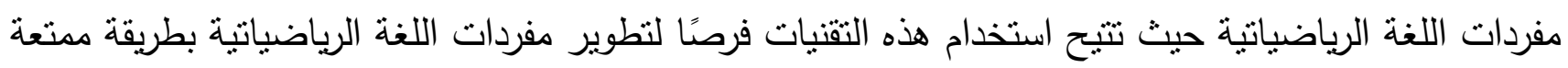
وترفيهية ومحفزة للأطفال. (Riccomini, P. J., et al, 2015, 240-246) وثُرجع الباحثة تفوق الأطفال (عينة البحث) في القياس البعدى مقارنة بالقياس القبلى على اختبار اللغة

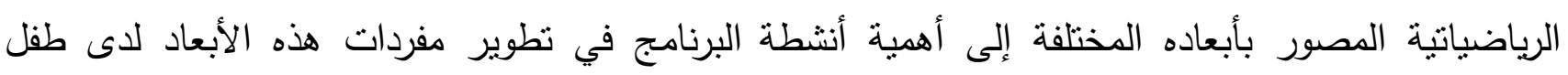

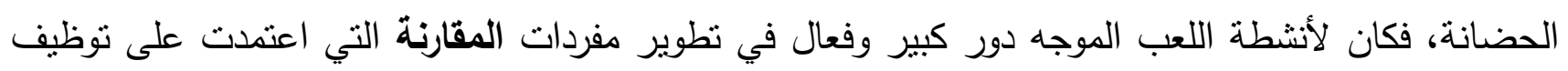

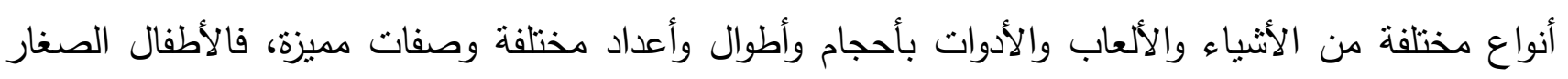

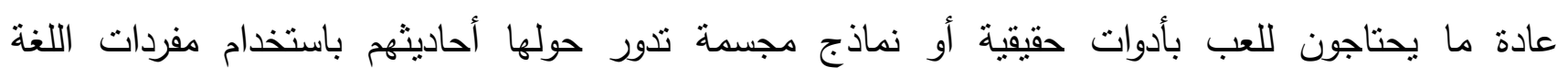

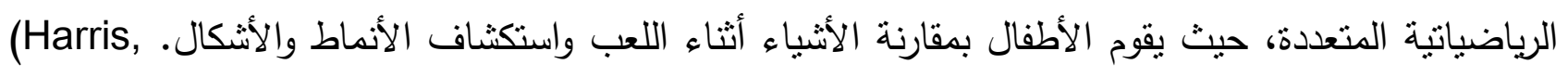
B., Petersen, D., 2019, 2)

حيث يتعلم الأطفال الصغار مفردات اللغة الرياضياتية الخاصة بالقياس، فالكلمات الرياضياتية منتشرة إلى لى

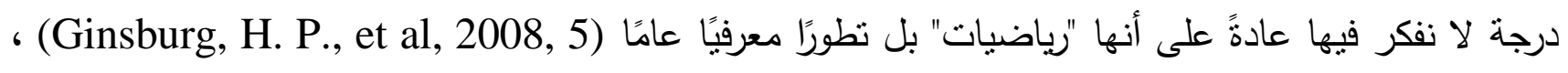

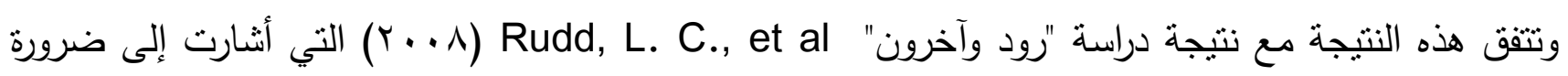

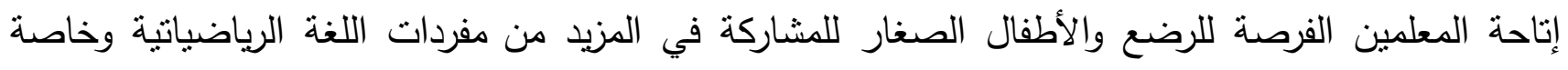
المتعلقة بالقياس في الفصول الدراسية. (Rudd, L. C., et al, 2008, 80)

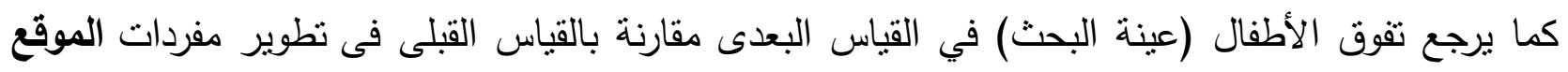

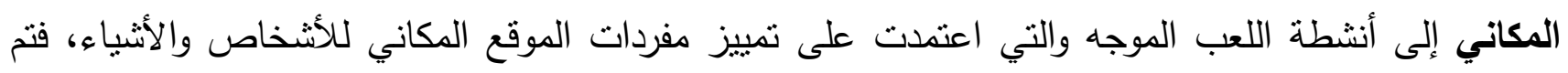

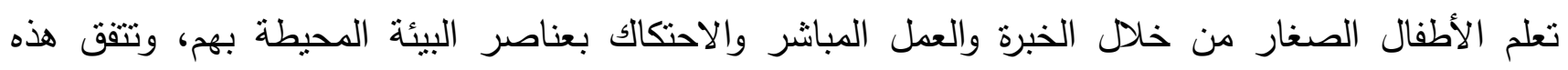

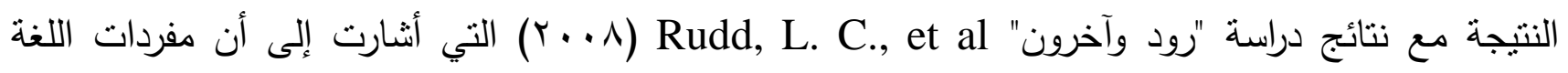
الرياضياتية المتعلفة بالعلاقات المكانية هي أكثر الأنواع المستخدمة في إعدادات الطفولة المبكرة. 
وكذللك يرجع تفوق الأطفال (عينة البحث) في القياس البعدى مقارنة بالقياس القبلى فى تطوير مفردات الأشكال الهندسية إلى أنشطة اللعب الموجه والتي اعتمدت على ملاحظة الطفل للمادة المتعلمة ومشاركته الإيجابية في

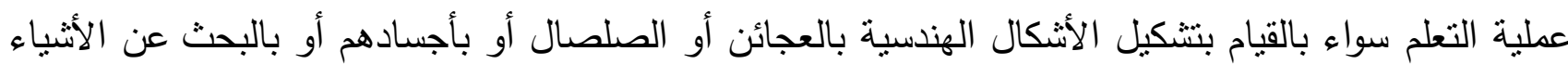

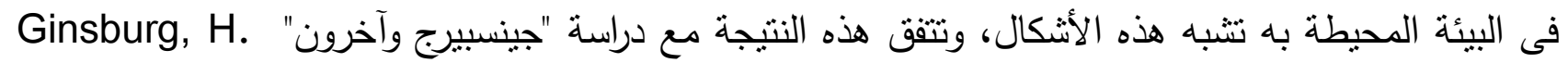

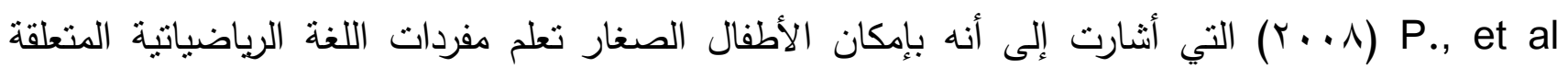
بالأثكال الهندسية. (Ginsburg, H. P., et al, 2008, 5)

كما يرجع تفوق الأطفال (عينة البحث) في تطوير مفردات الزمن إلى أنشطة اللعب الموجه التي تم فيها قيام

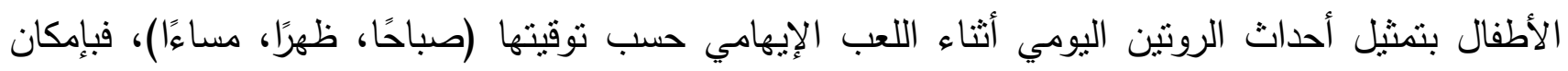

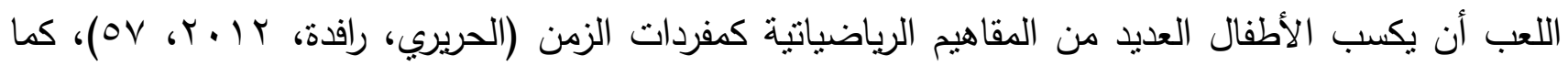

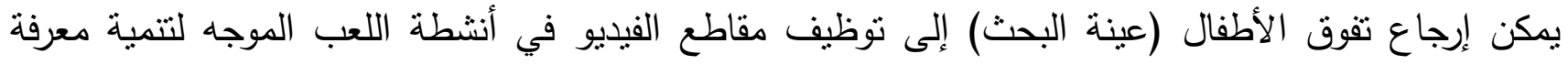

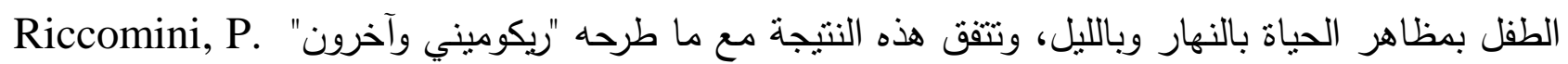

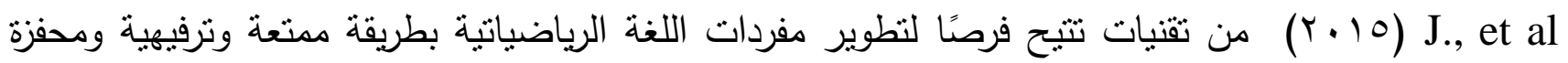
للأطفال منها تقنية التطبيقات التكنولوجية. (Riccomini, P. J., et al, 2015, 240-246)

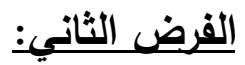

توجد فروق دالة إحصائيًا بين متوسطات درجات أطفال المجموعة التجريبية في القياسين البعدي والتتبعي على اختبار اللغة الرياضياتية المصور لطفل الحضانة في اتجاه القياس التتبعي.

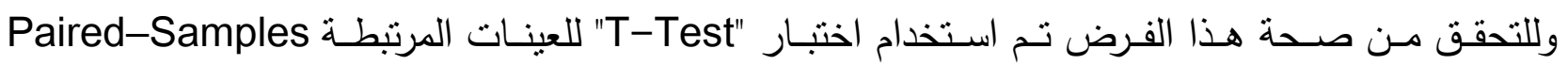
ويوضح جدول (9) التالي نتائج ذللك:

(9) جدول (9)

نتائج اختبار "T-Test" لالالة الفروق بين متوسطات درجات المجموعة التجريبية في القياسين البعدي والتتبعي على اختبار

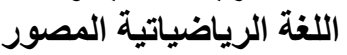

$$
\text { ن }
$$

\begin{tabular}{|c|c|c|c|c|c|c|c|}
\hline \multirow[t]{2}{*}{ اتجاه الدلالة } & \multicolumn{2}{|c|}{ 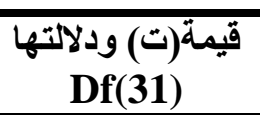 } & \multicolumn{2}{|c|}{ التبعى } & \multicolumn{2}{|c|}{ البعدى } & \multirow[t]{2}{*}{ المتغيرات } \\
\hline & الدلالة & القيمة & الالعيارى اف & المتوسط & الالانحر اف & المتوسط & \\
\hline في اتجباه القياس & $\because .1$ & $r . r$ & $\cdot . \leqslant 9$ & 9.7 & .70 & 9.4 & المقارنة \\
\hline في اتجباه القياس & $\because \cdot 1$ & $0 . \wedge 1$ & $\cdot . T V$ & v. 0 & $\cdot . V V$ & T.V & الموقع المكانى \\
\hline في اتجاه القياس & $\because .1$ & r.VA & ת & V.A & $\cdot . \leqslant 9$ & v. .7 & الأثنكال الهندسية \\
\hline في اتجاه القباس & $\because .1$ & T. & • $\varepsilon r$ & 纟.. & $\cdot . \varepsilon r$ & $\varepsilon . Y$ & الزمن \\
\hline
\end{tabular}




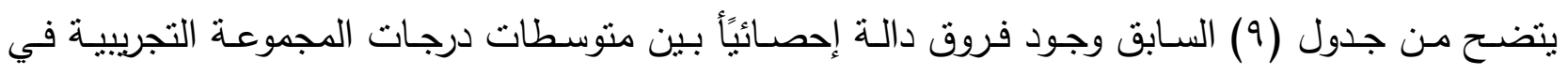
القياسين البعدي والتتبعي على اختبار مفردات اللغة الرياضياتية المصور ( المقارنة، الموقع المكاني، الأثكال الهندسية، الزمن ) لصالح القياس التتبعي.

\section{تفسير ومناقثة نتائج الفرض الثاني:}

أسفرت نتائج الفرض الثاني عن وجود فروق دالة إحصائيًا بين متوسطات درجات المجموعة التجريبية في

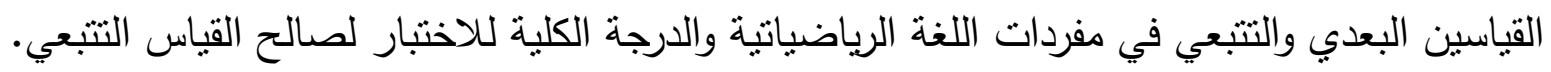
وتُرجع الباحثة هذه النتيجة إلى امتداد أثز البرنامج الذي اعتمد على تقديم المفاهيم من خلال التفاعل المباشر مع الأثياء والمواقف في البيئة، فاستطاع الطفل تكوين الكثير من المفاهيم عن طريق ربطها بأفئهال أو أو أعمال

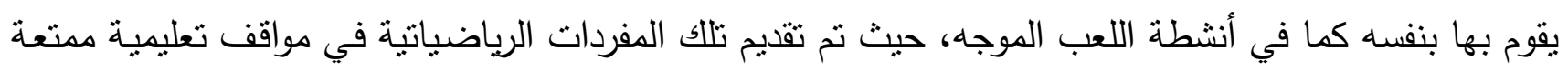

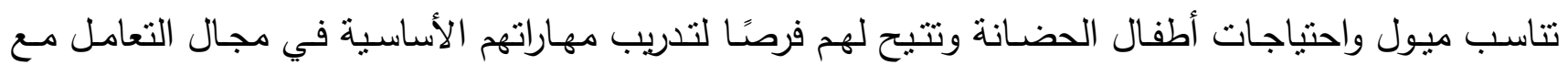

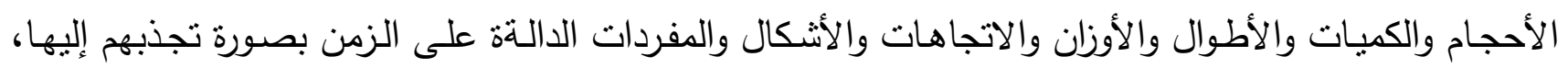
بحيث يرغبون في تكرارها بما يسمح لهم بتدريب هذه المهارات في جو من الألفة الجماعية والفردية.

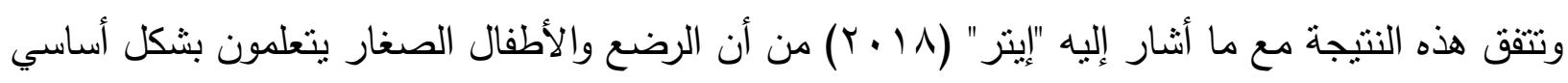

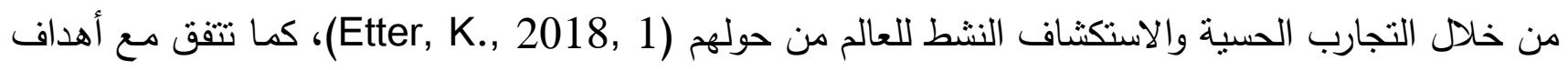

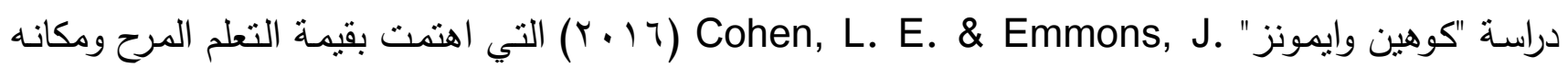

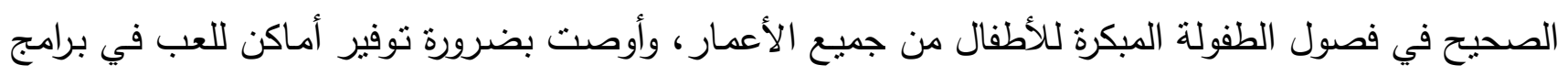
الطفولة المبكرة.

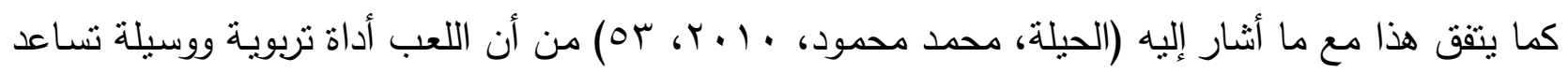

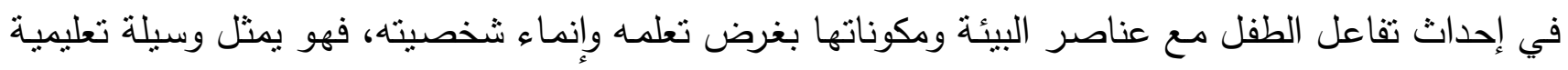
تقرب المفاهيم إلى الأطفال وتناعدهم على إدراك معاني الأثنياء والتكيف مع واقع الحياة.

كما ترجع الباحثة هذه النتيجة إلى التفاعل الإيجابي للأطفال أثناء تطبيق أنشطة البرنامج المتتوعة والمحبية للطفل مما ساعد على الاحتفاظ بأثز التعلم والذي ظهر جلياً في القياس التنبعي.

فعندما يركز المعلمون على اللغة الرياضياتية ويعرضون المفاهيم الرياضياتية في جو من المرح وطرق الانخراط يكون الأطفال متحمسين لتعلم المفاهيم التي تتجاوز ما هو منوقع عادة من سنهم. Rudd, L. C., et) al, 2008, 77)

كذلك يمكن إرجاع هذه النتيجة إلى توافر البيئة العاطفية أثناء تطبيق البرنامج المحفزة للعب الأطفال، وتتفق

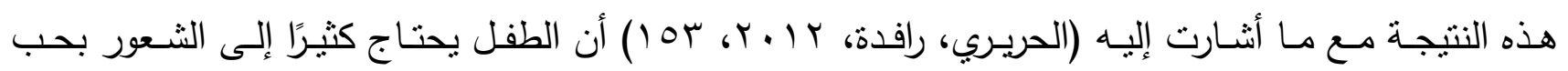


المحيطين به ممن يولونه الرعاية والاهتمام، كما أنه يحب ذاته ويشعر بقبول من حوله، فالحب والمودة والتعاطف مع الآخرين هو مفتاح التربية ويجب غرسها في الطفل أثناء لعبه وتعامله مع الآخربن. توصياث البحث:

ا ـ إعداد بيئة مناسبة للعب تشمل المكان المناسب وتوافر الألعاب والتجهيزات والمواد. r. ضرورة توافر حديقة بالحضانة بمساحة مناسبة لممارسة الطفل كافة أنشطة اللعب الموجه. ץ. اعتماد اللعب (الحر، الموجه) استراتيجية أساسية ورسمية في تعليم وتعلم الطفل في الحضانات الحكومية والأهلية.

ع. إعداد دليل للمعلمة يتتاول أنشطة اللعب الموجه لتطوير اللغة الرياضياتية لدى طفل الحضانة. 0. رفع مستوى وعي المعلمات بأهمية اللعب الموجه في برامج ومناهج الحضانة. 7. تدريب المعلمات على توظيف أنشطة اللعب الموجه في جميع مجالات منهج الحضانة. بحوث ودراسات مقترحة:

ا ـ برنامج لتوعية أولياء الأمور بأهمية تطوير اللغة الرياضياتية من خلال الأنشطة المنزلية. r ب. برنامج قائم على ألعاب الطبخ لتطوير اللغة الرياضياتية لدى طفل الحضانة. r. برنامج لتدريب المعلمة على توظيف أنشطة اللعب الموجه لاكساب طفل الحضانة بعض المفاهيم. ء. برنامج قائم على بعض التطبيقات التكنولوجية لنطوير اللغة الرياضياتية لدى طفل الحضانة. ه. دراسة تقويمية عن واقع تطوير المعلمة للغة الرياضياتية لدى طفل الحضانة. 7. فاعلية برنامج لتتمية بعض مهارات القياس لدى طفل الحضانة. V. فاعلية برنامج لتتمية بعض مفاهيم الزمن لدى طفل الحضانة. 
ا. جاب الله، ماجدة خضر (10 • (1). جودة تصميم الحديقة بدور الحضانة وعلاقتها بالنمو المتكامل للطفل

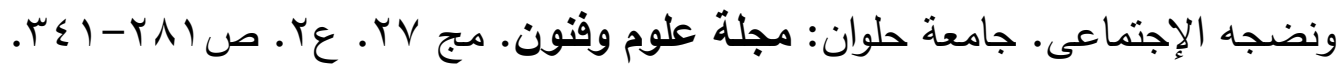

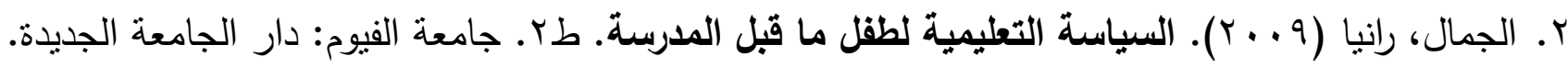

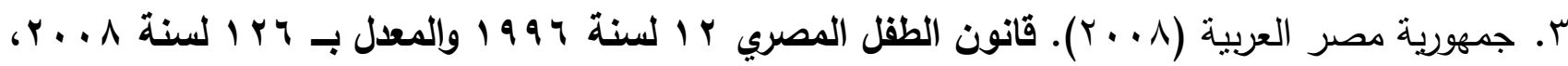
المجلس القومي للطفولة والأمومة.

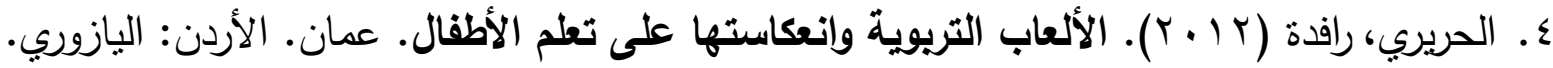

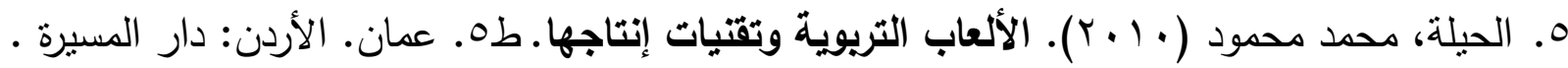

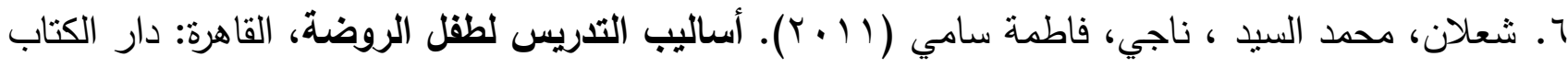
الحديث. V. صالح، ماجدة محمود (10 • (ץ). تلريس الرياضيات بين النظرية والتطبيق، الاسكندرية: دار المعرفة

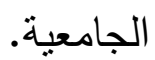

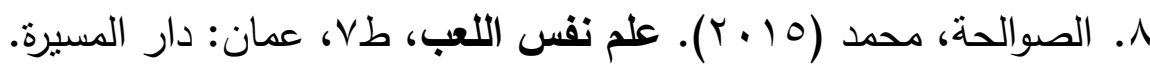

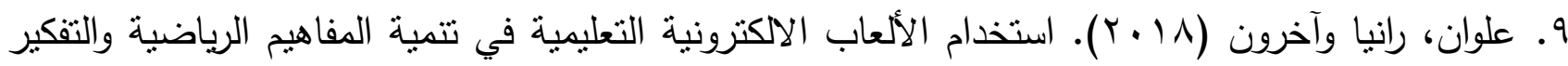
الابتكاري لاى طفل ما قبل المدرسة. المؤسسة العربية للعلوم التربوية والنفسية: المجلة العربية للعلوم

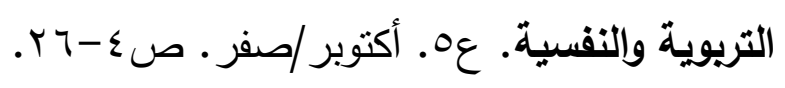

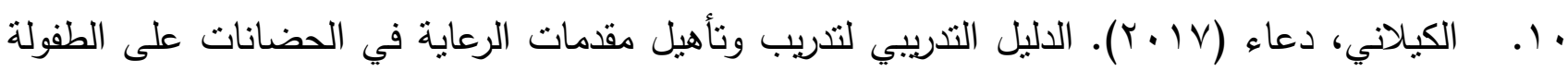

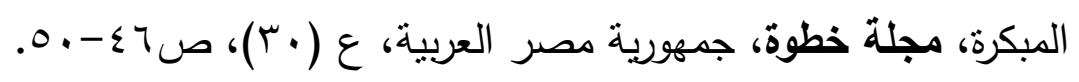

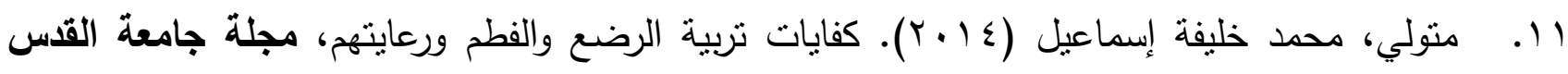

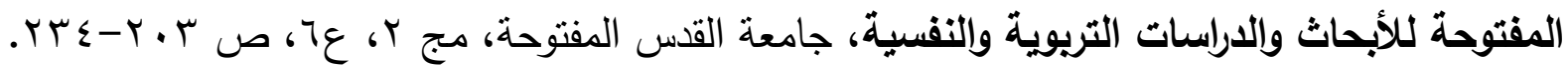

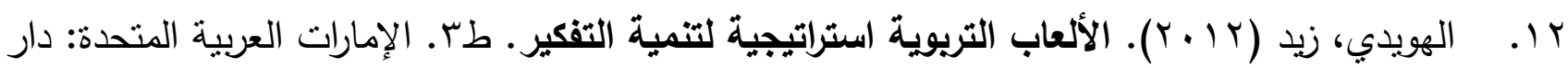

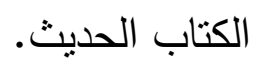

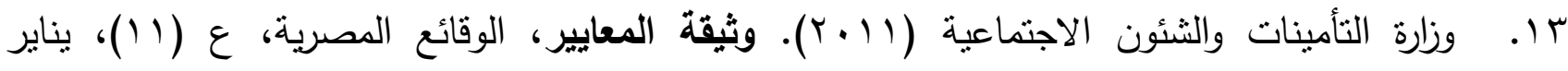

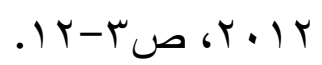

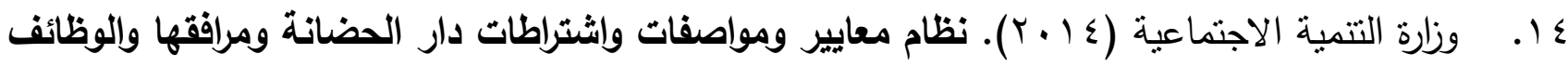
فيها، مملكة البحرين. 


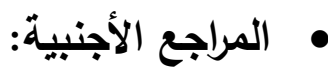

1. Clements, D. H., \& Sarama, J., (2011): Early Childhood Mathematics Intervention, Science, P (968-970).

2. Clements, D. H., \& Sarama, J., (2014): Learning and teaching early math: The learning trajectories approach (Second ed.), New York: Routledge.

3. Clements, D. H., (2013): Mathematics in Early Childhood Learning, National Council of Teachers of Mathematics.

4. Cohen, L. E. \& Emmons, J. (2016): Block play: spatial language with preschool and school-aged children, Early Child Development and Care, DOI: 10.1080/03004430.2016.1223064.

5. Etter, K., (2018): A Guide to Using the Creative Curriculum for Infants, Toddlers \& Twos to Support Farm-to-ECE Models, Policy Equity, Kellogg Foundation.

6. Fisher, K. R., et al (2013): Taking shape: Supporting preschoolers' acquisition of geometric knowledge through guided play, Child Development, V(84), $\mathrm{N}(6), \mathrm{P}(1872-1878)$.

7. Frye, D., et al (2013): Teaching math to young children: A practice guide (NCEE 2014-4005), Washington, DC: National Center for Education Evaluation and Regional Assistance (NCEE), Institute of Education Sciences, U.S. Department of Educa-tion. Retrieved from the NCEE website: http://whatworks.ed.gov.

8. Geetha R. B., \& Eason, S. H., (2015): learning early math through play and games, Play and the Common Core, V (96), N (8), P (27-32).

9. Ginsburg, H. P., et al (2008): Mathematics Education for Young Children: What It is and How to Promote It?, Social Policy Report: Giving Child and Youth Development Knowledge Away, the Society for Research in Child Development, V (XXII), N (I), P (3-24). 
10. Greenberg, J., (2012): "More, All Gone, Empty, Full: Math Talk Every Day in Every Way, YC Young Children, National Association for the Education of Young Children, V (67), N (3), p (62-64).

11. Harris, B., \& Petersen, D., (2019): Developing Math Skills in Early Childhood, Princeton, NJ: Mathematica Policy Research.

12. Harris, B., et al (2017): Issue brief: Integrating mathematical thinking into family engagement programs. Princeton, NJ: Mathematica Policy Research.

13. National Resource Center (2012): Supporting Early Learning for Infants and Toddlers | Where is the Math? News You Can Use.

14. Özdogan, E., (2011): Play, mathematic and mathematical play in early childhood Education, Social and Behavioral Sciences, V (15), P (3118-3120).

15. Riccomini, P. J., et al (2015): The Language of Mathematics: The Importance of Teaching and Learning Mathematical Vocabulary, Reading and Writing Quarterly, Taylor \& Francis Group, LLC, N (31), P (235-252), July 2015.

16. Rudd, L. C., et al, (2008): Mathematical language in early childhood settings: What really counts? Early Childhood Education Journal, N (36), P (75-80).

17. Sarama, J., et al (2012). The impacts of an early mathematics curriculum on emerging literacy and language. Early Childhood Research Quarterly, 27, P (489-502).

18. Smith, S.S. (2001): Early Childhood Mathematics, Allyn and Bacon, A Pearson Education Company, USA.

19. Weisberg, D.S., et al (2013): Guided play: Where curricular goals meet a playful pedagogy, Mind Brain and Education, V (7), N (2), P (104-112).

20. Whitman, E., (2015): Teacher Mathematics Language: Its Use in the Early Childhood Classroom and Relationship with Young Children's Learning, Theses and Dissertations, Loyola University, Chicago. 